\title{
Microalgal Cell Biofactory-Therapeutic, Nutraceutical and Functional Food Applications
}

\author{
Boda Ravi Kiran (1) and S. Venkata Mohan* \\ Bioengineering and Environmental Sciences Lab, Department of Energy and Environmental Engineering (DEE), \\ CSIR-Indian Institute of Chemical Technology (CSIR-IICT), Hyderabad 500 007, India; \\ ravikiranboda89@gmail.com \\ * Correspondence: vmohan_s@yahoo.com or svmohan@iict.res.in; Tel.: +91-40-27191765
}

\footnotetext{
check for updates

Citation: Kiran, B.R.;

Venkata Mohan, S. Microalgal Cell Biofactory-Therapeutic,

Nutraceutical and Functional Food Applications. Plants 2021, 10, 836. https://doi.org/10.3390/ plants10050836
}

Academic Editor: Sousuke Imamura

Received: 16 March 2021

Accepted: 18 April 2021

Published: 21 April 2021

Publisher's Note: MDPI stays neutral with regard to jurisdictional claims in published maps and institutional affiliations.

Copyright: (c) 2021 by the authors. Licensee MDPI, Basel, Switzerland. This article is an open access article distributed under the terms and conditions of the Creative Commons Attribution (CC BY) license (https:// creativecommons.org/licenses/by/ $4.0 /)$.

\begin{abstract}
Microalgae are multifaceted photosynthetic microorganisms with emerging business potential. They are present ubiquitously in terrestrial and aquatic environments with rich species diversity and are capable of producing significant biomass. Traditionally, microalgal biomass is being used as food and feed in many countries around the globe. The production of microalgal-based bioactive compounds at an industrial scale through biotechnological interventions is gaining interest more recently. The present review provides a detailed overview of the key algal metabolites, which plays a crucial role in nutraceutical, functional foods, and animal/aquaculture feed industries. Bioactive compounds of microalgae known to exhibit antioxidant, antimicrobial, antitumor, and immunomodulatory effects were comprehensively reviewed. The potential microalgal species and biological extracts against human pathogens were also discussed. Further, current technologies involved in upstream and downstream bioprocessing including cultivation, harvesting, and cell disruption were documented. Establishing microalgae as an alternative supplement would complement the sustainable and environmental requirements in the framework of human health and well-being.
\end{abstract}

Keywords: bioactive compounds; food supplements; health and nutrition; immunostimulants; algal metabolite extraction

\section{Introduction}

Prognoses speculate the world population to reach almost 9.5 billion by 2050 and the food produced must be increased two-fold to meet the global necessities [1]. Escalating agricultural area, crop rotation, and yield increase could meet the rising demands for food; nevertheless, these practices deepen the existing environmental problems i.e., deforestation, soil degradation, and loss of biodiversity [2-4]. In this perspective, microalgae are emerging as a sustainable feedstock and alternative food source [5]. The primordial theory suggests that life began in a water body (ocean/ponds) and within the earth's biome, algal strains are characterized by high biodiversity [6]. Microalgae present in freshwater and marine environments are unicellular, microscopic, and photosynthetic microorganisms. Rapid proliferation rate, high photosynthetic activity, $\mathrm{CO}_{2}$ sequestration, biomass production, and ability to grow on wastewater makes algae an amenable microbe for the production of value-added biochemicals [7-9]. Globally, 7000 tons of dry algal biomass is produced with a market value of 3800 to 5500 million USD per annum [10]. Utilizing microalgal biomass for developing pharmaceuticals, nutraceuticals, and functional foods for health benefits is rapidly soaring. For example, Chlorella and Arthospira species (2000 and 5000 tons/year) are dominant dietary supplements with a global production of USD 40 million/year [11]. The worldwide Spirulina market is valued at USD 629.6 million, and it is anticipated to reach a CAGR of $9.4 \%$ by 2025 [12]. Bioactive compounds synthesis has spread all over the world including countries with higher temperatures as well as longer-sunlightduration countries (Southern Asia, Middle East, Central, and South America), which allows for more cost-effective cultivation of microalgae [13]. This communication will 
make an attempt to unravel the significance of microalgae metabolites in relation to dietary supplements, therapeutic activity, and utilization as feed in poultry and aquaculture farming. The cultivation, downstream process, pre-treatment, and product fractionation were also reviewed.

\section{Potential of Microalgae}

The global nutraceutical and pharmaceutical markets in 2017 were worth USD 200.2 billion and USD 934.8 billion, respectively, and are expected to hit USD 317.3 billion and USD 1170 billion by 2024, respectively [14,15]. Microalgae are essential life forms, which produce $\sim 50 \%$ of atmospheric oxygen and function as a backbone of the food web along with bacteria supplying energy to all trophic stages [16]. Utilizing wastewater as nutrients and processing value-added products on non-arable land helps to avoid competition with food crops [17]. From a compositional viewpoint, microalgae are rich in carbohydrates (50\% of dry biomass), and the absence of lignin makes them highly amenable to access sugar content without any pretreatment, which is a prerequisite in plant materials [6]. Since World War II, they have been well known for their possible bioactive compounds that support humankind [18]. Bioactive compounds occur as a part of the food chain with functional properties.

According to an estimate, there are around 200,000 to 800,000 species of microalgae and more than 15,000 novel algal biomass compounds that have been identified [19]. Microalgae are light-driven cell factories that synthesize bioactive compounds from primary metabolites (lipids, proteins, and carbohydrates) and secondary metabolites (pigments, carotenoids, vitamins, and sterols) at various growth stages. Spirulina, Porphyridium, and Scenedesmus are excellent sources of protein $(60-70 \% w / w)$, carbohydrates $(40-60 \% w / w)$, and lipids $(40 \% w / w)$ [5]. These metabolites are produced from microalgae via mevalonate/ non-mevalonic, shikimate, and polyketide pathways. Proteins, lipids, and carbohydrates synthesized in the growth phase act as energy reservoirs during nutrient deficient conditions [20,21]. Each microalgal species has diverse characteristics and produces various products influenced by both biotic and abiotic stress.

Microalgae produce various therapeutically active bio-compounds either from biomass/deoiled mass or unleashed directly into the extracellular matrix [22]. Phenylalanine ammonia-lyase, an enzyme active in the biosynthesis of polyphenol compounds (phenylpropanoids, flavonoids, and lignin) was characterized by X-ray crystallography in Anabaena variabilis and Nostoc punctiforme [23]. Reactive oxygen species (ROS) that inflict oxidative damage to proteins, lipids, and nucleic acids contribute to cancer, atherosclerosis, rheumatoid arthritis, heart disease, Alzheimer's, Parkinson's, and accelerates aging in humans. Microalgal metabolites have potent biological processes viz. antioxidant, anti-inflammatory, antifungal, anti-microbial, anti-enzymatic, antiviral, anticancer, anticoagulant, and immunosuppressant effects, which help in the reduction and prevention of diseases [24]. Microalgae are renowned as a rich source of biological metabolites with applications in pharmaceuticals, food, feed, and skincare products. Furthermore, the elemental microalgae abundance in terms of $\mathrm{C}, \mathrm{H}, \mathrm{O}$, and $\mathrm{N}$ is two-times higher than wood and acts as a notable organic fertilizer [25]. Primal Healthcare, Rincon pharmaceuticals, Agri Life SOM Phytopharma, and Novo Nordisk India Pvt. Ltd., use micro- and macroalgae bioactive compounds in vaccine development that confer immunity against infectious diseases [11].

\section{Bioactive Compounds}

Scientists are diligently exploring to increase algal biomass especially rich in nutraceutical substances that can be utilized as whole cell or extracts and added as ingredients in foods and beverages (Table 1). 


\subsection{Chlorophyll}

Chlorophyll is an omnipresent pigment (lipid-soluble) crucial for photosynthesis and in general found in all plants, algae, and cyanobacteria. Green microalgae Chlorella sp. is popularly called "Emerald food" because of its high chlorophyll content [26]. Chlorophyll $a$, $b$, or a standalone mixture exhibited chemo-preventive effects such as elevated glutathione S-transferase levels, cytochrome P450 enzyme inhibition, and cellular differentiation; albeit mitotic arrest and necrobiosis [27]. Chlorophyll gained significance as a dyeing agent in food and due to chemotherapeutic potential because of its derivatives in the field of medicine [28]. It is widely used as a constituent in health and hygiene products such as antiperspirants, air fresheners, lozenges, and in formulations against foul smells.

\subsection{Carotenoids}

Carotenoids are hydrophobic, light-harvesting accessory pigments with the $\mathrm{C}_{40}$ backbone structure of isoprene units, which act as antioxidants and play a major role in quenching free radicals and inhibiting oxidative injury to cells, tissues, and membranes [29]. Approximately 400 carotenoids were identified in different living beings, and those that are widely commercialized are $\beta$-carotene, astaxanthin, lutein, fucoxanthin, zeaxanthin, antheraxantin, violaxanthin, neoxanthin, loroxanthin, diadinoxanthin, diatoxanthin, and siphonein [30]. The global market value of carotenoids was USD 1.5 billion in 2017 and should reach USD 2.0 billion by 2022 at a compound annual growth rate of $5.7 \%$ (www.bccresearch.com, accessed on 15 March 2021). Botryococcusbraunii, Chlamydocapsa sp., Chlamydomonas nivalis, Chlorella sorokiniana, Chlorococcum sp., Dunaliella salina, Dunaliella tertiolecta, and Paeonia obovate, belonging to Chlorophyceae and Trebouxiophyceaeare are dominant microalgal species-rich in $\beta$-carotene [31]. Astaxanthin (ASX) is a red xanthophyll pigment and is the most industrially exploited ketocarotenoid with a market value of USD 200 million [32]. Astaxanthin exhibits greater antioxidant function, i.e., 100 times higher than alpha-tocopherol, 6000 times as much as vitamin C, 800 times as much as coenzyme Q10, 550 times as much as vitamin E, 200 times as much as polyphenols, 150 times as much as anthocyanins, and 75 times as much as alpha-lipoic acid [33]. Lutei is a goldencolored carotenoid with an annual production of 70-150 tons/ha, i.e., 11.5-25 times that of marigold (6 tons) and a market value of USD 3.14 million [34]. It exhibits higher antioxidant activity than $\beta$-carotene in attenuating oxidative damage and preventing damage to lipid bilayers [35]. The global market of fucoxanthin was USD 600 million in 2020 and is anticipated to reach USD 780 million by the end of 2025, growing at a compound annual growth rate of $6 \%$ between 2020 and 2025 [36]. It was first commercially produced by $\mathrm{Al}-$ gatechnologies Ltd. in 2018 with a trademark Fucovital ${ }^{\circledR}$ mainly employed in bodyweight management products.

\subsection{Lipids}

Lipids are essential macromolecules and critical constituents of energy reservoirs and signaling, molecules crucial for the integrity and functionality of cellular membranes. Algae contain most of the plant lipids such as glycosylglycerides and phosphoglycerides [37]. Microalgae lipid content varies from 1 to $40 \%$, and it may rise to $85 \%$ of total dry weight depending upon nutrient composition, temperature, light flux, and $\mathrm{CO}_{2}$ concentration [38]. Storage lipids (triacylglycerols) are produced via photosynthesis and stored in cells, whereas fats involved in cell structure and metabolism are known as structural lipids (monounsaturated fatty acids (MUFA) and poly monounsaturated fatty acids (PUFA)). PUFAs are long unsaturated hydrocarbons with more than one double bond and have potent applications in feed and nutraceutical industries. They play a prominent role in balancing membrane fluidity, electron and oxygen transport, thermal adaptation, as well as cellular and tissue metabolism [39]. Microalgae are rich in long-chain PUFAs such as $\gamma$-linoleic acid (18:3), arachidonic acid (20:4), eicosapentaenoic acid (20:5), and docosahexaenoic acid (22:6). Docosahexaenoic acid (DHA) and eicosapentaenoic acid (EPA) are abundant omega-3 fatty acids with a market value of 80 to $160 \mathrm{USD} \mathrm{kg}^{-1}$ and the global value is predicted 
to be USD 898.7 million by 2025 [22]. Humans are unable to synthesize lipids themselves endogenously, and external administration in diet is crucial for maintaining hemostasis [40]. PUFA reduces the prevalence of several chronic diseases and has proven to have several health benefits, i.e., the central nervous system and human vision reinforced by FDA (Food and Drug Administration) and FAO (Food and Agricultural Organization) [11]. The balanced diet ratio of polyunsaturated fatty acids to saturated fatty acids recommended by the World Health Organization (WHO) and the FDA should be above 0.4 and prescribed intake should be 0.2-0.3 g DHA and EPA per day for a healthy individual [41]. Dihomo- $\gamma-$ linolenic acid (DGLA), a trace amount long chain PUFA is important in developing infant formulations [36]. Chaetoceros calcitrans, Crythecodinium cohnii, Isochrysis galbana, Monodus subterraneus, Nannochloropsis sp., Pavlova salina, Phaeodactylum tricornutum, and Porphyridium cruentum are some of the PUFAs producing microalgal species [42,43].

\subsection{Carbohydrates}

Carbohydrates are major intracellular components acquired from photosynthesis and can reach up to $50 \%$ of microalgae dry weight. Carbohydrates are synthesized in the form of reducing sugars like glucose, lactose, sucrose, fructose, and polysaccharides [44]. Polysaccharides have attracted widespread attention from bioengineering and pharmaceutical companies as they are natural, biodegradable, non-toxic, and biocompatible. These provide health benefits by boosting the immune system, blocking tumorigenesis, and were first exploited for their rheological property as thickening or gelling agents [11]. $\beta-1,3$ glucan, an agile immunostimulator from Chlorella, alleviates hydroxyl radicals, atherosclerosis, gastric ulcers, cholesterol, constipation, and hypercholesterolemia [45]. Polysaccharides, namely immulina and immurella isolated from Spirulina platensis and Chlorella pyrenoidosa, exhibited high anticancer activity when compared to fungal polysaccharides such as schizoplyllan, lentinan, and krestin [46]. Animals fed with polysaccharide-rich algae exhibited lower cholesterol levels in serum with the subsequent reduction in insulin and glucose [47]. Sulfate ester-containing algal polysaccharides are classified as sulfated polysaccharides and are mainly produced by Chlorella vulgaris and Scenedesmus quadricauda. These polysaccharides consist of 3-linked $\beta$-D-galactose and 4-linked $\alpha$-D-galactose as alternate remnants in their backbone [48]. Sulfated polysaccharides produced from Porphyridium aerugineum act as a coating material on the surface of sanitary items to prevent infections from epidemic diseases like COVID-19 [49].

\subsection{Proteins}

Proteins are building blocks and essential macro-nutrients responsible for the overall growth of human body. Compared to animal-based proteins (42-52 $\mathrm{m}^{2}$ for chicken, $47-64 \mathrm{~m}^{2}$ for pork, and $144-258 \mathrm{~m}^{2}$ for beef production), microalgae proteins $\left(<2.5 \mathrm{~m}^{2}\right.$ per $\mathrm{kg}$ of protein) require minimal land for cultivation [50]. Algal proteins are used as a dietary supplement (tablets, powder, and paste), and the amino acid composition is equivalent to high-quality protein foods such as $\beta$-lactoglobulin, tofu, mushrooms, soybean, and egg white [51]. Chlorella sp., Dunaliella sp., and Arthrospira sp. produce top-notch proteins and amino acid profiles according to FAO/WHO guidelines and are legally marketed as nutraceuticals or fortified foods to prevent health disorders and abnormalities in cells. Spirulina contains $50-70 \%$ protein (dry weight) and essential amino acids, such as isoleucine, leucine, and valine, which exhibit high digestibility (83-90\%). A spoonful of Spirulina $(7 \mathrm{~g})$, of which dried biomass contains almost $4 \mathrm{~g}$ of protein, is also known as a "superfood" by the World Health Organization [17]. Hainan Simai Pharmaceutical Co. Ltd., Haikou in China annually produces around $3 \times 10^{3}$ tons of Spirulina biomass. Cyanotech (Hawaii, USA) under the name Spirulina Pacifica produces and markets products (http:/ / www.cyanotech.com, accessed on 2 September 2009). Microalgas Macronutricao factory in Brazil produces Spirulina lozenges for dietary nourishments (http://www.olson.com.br, accessed on 14 July 2001). Phycobiliprotein are hydrophilic protein-pigment complexes present only in cyanobacteria. These are used as 
fluorescent labels in antibodies and receptors, flow-cytometry, immunohistochemistry, immunoblotting experiments, and microscopy or fluorescence diagnosis [52]. Triton Health and Nutrition (USA) and Algenics (France) are the first manufacturers to use microalgae in high-throughput recombinant protein expressions. Chlamydomonas reinhardtii and Chlamydomonas elipsoidea contain recombinant proteins viz. vascular endothelial growth factor (VEGF), erythropoietin, Human IgG $\alpha$ PA83, hGAD65, immunotoxin $\alpha$ CD22-PE40, Plasmodium surface proteins (AMS1, MSP1, VP28, Pfs25, Pfs28, CtxB-Pfs25 and Pfs 48/45), Anti-CD-22-gelonin, lsc $\alpha$ HSV glycoprotein D, CSFV-E2, hTRAIL, and Anti-PA 83 anthrax IgG1, which possess therapeutical applications in anemia treatment, wound healing, anti-malarial vaccines, and as an antibody against anthrax, Herpes simplex virus, human papillomavirus, and foot-and-mouth disease [10,53,54]. Besides these, it functions as an immunotoxin against B-cell lymphoma and has increased resistance to UV-induced stress [55].

\subsection{Vitamins}

Microalgae are the cradle homes of vitamins that can be used as ingredients or food supplements to nourish the human body, revitalize cells, detoxify, as well as activate the immune system [56]. Vitamin A ( $\beta$-carotene), vitamin C, E, and B i.e., thiamine (B1), riboflavin (B2), niacin (B3), pantothenic acid (B5), pyridoxine (B6), folic acid (B9), and cyanocobalamin (B12) are commonly produced vitamins. Vitamin B12 and provitamin A ( $\beta$-carotene) are rich in Spirulina, which upon consuming, improves Lactobacillus in the intestine and makes it possible to digest vitamin B1 and other vitamins from food more efficiently [57]. Lutein and Zeaxanthin synthesized from Spirulina maximaare rich in vitamin $\mathrm{A}$ and act as protective factors from harmful light sources and age-related macular degeneration (AMD) [41]. Anabaena cylindrica, a cyanobacterium, produces a high concentration of vitamin K1 $\left(200 \mu \mathrm{g} \mathrm{g}^{-1}\right)$, which plays a significant role in the inhibition of chronic ailments [58]. Microalgae containing vitamin $\mathrm{D}_{2}$ and $\mathrm{D}_{3}$ together with provitamin $\mathrm{D}_{3}$ acts as a chemopreventive agent and exerts antiproliferative and immunomodulatory activity on tumor-growing cells [59]. Vitamin E synthesized in microalgal species such as Chaetoceros calcitrans, Dunaliella tertiolecta, Nannochloropsis sp., Porphyridium sp., and Tetraselmis suecica improves endothelial function, vascular health, and inhibits prostate cancer cell growth [60].

Table 1. Microalgae bioactive metabolites and producers for human nutrition.

\begin{tabular}{|c|c|c|c|c|c|}
\hline S. No. & $\begin{array}{l}\text { Microalgae } \\
\text { Compounds }\end{array}$ & Pigment & Microalgae Species & Activity on Human Health & Reference \\
\hline 1. & Chlorophyll & Chlorophyll & $\begin{array}{c}\text { Chlorella sp., Sanropus } \\
\text { androgynous, Green algae }\end{array}$ & $\begin{array}{l}\text { Food additive, antioxidant } \\
\text { activity, immune activators, } \\
\text { cytotoxic towards } \\
\text { tumoral cells, }\end{array}$ & $\begin{array}{l}\text { Khanra et al., } 2018 \text { [28]; } \\
\text { Koller et al., 2014 [64]; } \\
\text { Mishra et al., } 2011 \text { [27]; } \\
\text { Odjadjare et al., } 2017 \text { [26]; } \\
\text { www.oligae.com (accessed } \\
\text { on } 15 \text { March 2021) }\end{array}$ \\
\hline \multirow{2}{*}{2.} & \multirow{2}{*}{ Carotenoids } & $\beta$-carotene & $\begin{array}{c}\text { Botryococcus braunii, } \\
\text { Chlamydomonas nivalis, } \\
\text { Chlamydocapsa sp., Chlorella } \\
\text { sorokiniana, Chlorococcum sp., } \\
\text { Chondria striolata, Dunaliella } \\
\text { salina, Dunaliella tertiolecta, and } \\
\text { Paeonia obovate }\end{array}$ & $\begin{array}{l}\text { Anti-aging, cancer, immune } \\
\text { control, coronary disease } \\
\text { prevention, retinal and } \\
\text { sensory disability } \\
\text { enhancement and } \\
\text { low-density lipoprotein } \\
\text { oxidation inhibition }\end{array}$ & $\begin{array}{l}\text { Andrade et al., } 2018 \text { [56]; } \\
\text { Barkia et al., } 2019 \text { [12]; } \\
\text { Galasso et al., } 2019 \text { [30]; } \\
\text { Gong and Bassi } 2016 \text { [31] }\end{array}$ \\
\hline & & Astaxanthin & $\begin{array}{l}\text { Ankistrodesmus braunii, } \\
\text { Chlamydomonas nivalis, Chlorella } \\
\text { vulgaris, Chondria striolata, } \\
\text { Haematococcus lacustris, } \\
\text { Haematococcus pluvialis, } \\
\text { Haematococcus sp., } \\
\text { Monoraphidium sp., } \\
\text { Scenedesmus obliquus }\end{array}$ & $\begin{array}{c}\text { Cancer defense, } \\
\text { inflammation, metabolic } \\
\text { syndrome, diabetes, } \\
\text { neurodegenerative and } \\
\text { ocular diseases, lung injury, } \\
\text { repressed alveolar wall } \\
\text { swelling and } \\
\text { myeloperoxidase activity }\end{array}$ & $\begin{array}{l}\text { Cai et al., } 2019 \text { [65]; } \\
\text { Capelli et al., } 2019 \text { [32]; } \\
\text { Chang et al., } 2010 \text { [66]; } \\
\text { Galasso et al., } 2019 \text { [30]; } \\
\text { Park et al., } 2010 \text { [67]; } \\
\text { Talukdar et al., } 2020 \text { [33]; } \\
\text { Wu et al., 2014 [68] }\end{array}$ \\
\hline
\end{tabular}


Table 1. Cont.

\begin{tabular}{|c|c|c|c|c|c|}
\hline S. No. & $\begin{array}{l}\text { Microalgae } \\
\text { Compounds }\end{array}$ & Pigment & Microalgae Species & Activity on Human Health & Reference \\
\hline & & Lutein & $\begin{array}{l}\text { Ankistrodesmus braunii, } \\
\text { Chlamydomonas acidophila, } \\
\text { Chlorella fusca, Chlorella } \\
\text { sorokiniana, Chlorococcum sp., } \\
\text { Tetraselmis suecica }\end{array}$ & $\begin{array}{l}\text { Antioxidant and anticancer } \\
\text { activity, prevents macular } \\
\text { degeneration, Cataract, } \\
\text { atherosclerosis, diabetic } \\
\text { retinopathy, and age-related } \\
\text { retinal degeneration }\end{array}$ & $\begin{array}{c}\text { Liu et al., } 2017 \text { [69]; } \\
\text { Rasmussen and } \\
\text { Johnson } 2013 \text { [70]; } \\
\text { Sansone et al., } 2017 \text { [71] }\end{array}$ \\
\hline & & Violaxanthin & & Anti-proliferative activity & Koller et al., 2014 [64] \\
\hline & & Canthaxanthin & $\begin{array}{l}\text { Chlamydocapsa sp., } \\
\text { Chlamydomonas nivalis, Chlorella } \\
\text { vulgaris, Chlorococcum sp., } \\
\text { Chlorella zofingiensis, } \\
\text { Neospongiococcum sp. }\end{array}$ & $\begin{array}{c}\text { Increases Vitamin E, } \\
\text { antioxidative, } \\
\text { anti-inflammatory and } \\
\text { neuroprotective properties }\end{array}$ & Sathasivam et al., 2019 [41] \\
\hline & & $\begin{array}{l}\text { Fucoxanthin and } \\
\text { Zeaxanthin }\end{array}$ & $\begin{array}{c}\text { Chaetoceros gracilis, } \\
\text { Chlamydomonas nivalis, } \\
\text { Dunaliella salina Isochrysis sp., } \\
\text { Ochromonas sp., Odontella aurita, } \\
\text { Phaeodactylum tricornutum, } \\
\text { Prymnesium parvum, } \\
\text { Salpingoeca marina }\end{array}$ & $\begin{array}{l}\text { Anti-cancer and } \\
\text { anti-proliferative properties, } \\
\text { prevention of osteoporosis, } \\
\text { rheumatoid arthritis and } \\
\text { diabetic diseases, } \\
\text { suppressing insulin } \\
\text { and hyperglycemia }\end{array}$ & $\begin{array}{l}\text { Gong et al., } 2016 \text { [31]; } \\
\text { Liu et al., } 2017 \text { [69] }\end{array}$ \\
\hline \multirow[b]{2}{*}{3.} & \multirow[b]{2}{*}{ Polysaccharides } & Polysaccharides & $\begin{array}{l}\text { Chlorella stigmatophora, } \\
\text { Phaeodactylum tricornutum, } \\
\text { Porphyridium cruentum, } \\
\text { Rhodella reticulata }\end{array}$ & $\begin{array}{l}\text { Antioxidant and } \\
\text { tumoricidal activity, } \\
\text { Reduces free radicals, } \\
\text { atherosclerosis, blood } \\
\text { cholesterol, gastric ulcers, } \\
\text { sores, constipation and } \\
\text { hypercholesterolemia }\end{array}$ & $\begin{array}{c}\text { Chen et al., } 2018 \text { [45]; } \\
\text { de Gardeva et al., } \\
2009 \text { [47]; Morais et al., } 2015 \\
\text { [46] }\end{array}$ \\
\hline & & $\begin{array}{c}\text { Sulfonated } \\
\text { polysaccharides }\end{array}$ & $\begin{array}{c}\text { Chlorophyta, Phaeophyta } \\
\text { and Rhodophyta }\end{array}$ & $\begin{array}{c}\text { Anticancer, antifungal, } \\
\text { hepatoprotective, } \\
\text { antihelminthic, } \\
\text { anti-protozoal, } \\
\text { anti-inflammatory, } \\
\text { anti-coagulant, } \\
\text { immunomodulation and } \\
\text { enhanced skin tissue } \\
\text { regeneration. Reducing } \\
\text { coronary heart disease and } \\
\text { acts as coating material on } \\
\text { the sanitary items for } \\
\text { COVID-19 prevention }\end{array}$ & $\begin{array}{l}\text { Gaikwad et al., } 2020 \text { [49]; } \\
\text { Lekshmi and Krupa } \\
2019 \text { [48]; Morokutti-Kurz } \\
\text { et al., 2017 [72]; Olasehinde } \\
\text { et al., } 2017 \text { [73]; Raposo } \\
\text { et al., } 2014 \text { [74] }\end{array}$ \\
\hline \multirow{4}{*}{4.} & \multirow{4}{*}{$\begin{array}{l}\text { Polyunsaturated } \\
\text { Fatty Acids } \\
\text { (PUFAs) }\end{array}$} & & $\begin{array}{c}\text { Chaetoceros calcitrans, } \\
\text { Crythecodinium cohnii, Isochrysis } \\
\text { galbana, Monodus subterraneus, } \\
\text { Nannochloropsis sp., } \\
\text { Pavlova salina, } \\
\text { Phaeodactylum tricornutum, and } \\
\text { Porphyridium cruentum }\end{array}$ & $\begin{array}{l}\text { Reduces occurrence of } \\
\text { chronic diseases such as } \\
\text { obesity, arthritis, diabetes, } \\
\text { cardiovascular diseases, } \\
\text { hypercholesterolemia and } \\
\text { improves brain function }\end{array}$ & $\begin{array}{c}\text { Bhalamurugan et al., } \\
2018 \text { [42]; Katiyar and } \\
\text { Arora } 2020 \text { [40]; } \\
\text { Mourelle et al., 2017 [37] }\end{array}$ \\
\hline & & $\begin{array}{l}\text { Eicosapentaenoic } \\
\text { acid (EPA) }\end{array}$ & $\begin{array}{c}\text { Chlorella vulgaris, } \\
\text { Nannochloropsis sp., Pavlova sp., } \\
\text { Tetraselmis sp. }\end{array}$ & $\begin{array}{l}\text { Immune activator, blood } \\
\text { clotting, regulation of blood } \\
\text { pressure and prevents } \\
\text { thrombosis, atherosclerosis } \\
\text { and beneficial for coronal } \\
\text { heart diseases }\end{array}$ & $\begin{array}{l}\text { Charles et al., } 2019 \text { [43]; } \\
\text { Levassuer et al., } 2020 \text { [11] }\end{array}$ \\
\hline & & $\begin{array}{l}\text { Docosahexaeonic } \\
\text { acid (DHA) }\end{array}$ & $\begin{array}{l}\text { Crypthecodiuimu sp., } \\
\text { Pyramimonas sp., Schizochytrium } \\
\text { sp., Thraustochytrid strain } 12 B\end{array}$ & $\begin{array}{c}\text { Anti-inflammatory, } \\
\text { anticancer function, used in } \\
\text { food for pregnant, nursing } \\
\text { and cardiovascular patients } \\
\text { as dietary supplements }\end{array}$ & $\begin{array}{l}\text { Long et al., } 2018 \text { [75]; } \\
\text { Raghukumar, } 2008 \text { [76]; } \\
\text { Teng et al., } 2015 \text { [77] }\end{array}$ \\
\hline & & $\begin{array}{l}\text { Arachidonic } \\
\text { acid (ARA) }\end{array}$ & $\begin{array}{l}\text { Navicula atomus, } \\
\text { Pediastrum boryanum, } \\
\text { Porphyridium } \mathrm{sp} .\end{array}$ & $\begin{array}{c}\text { Platelet aggregators, } \\
\text { vasoconstrictor, } \\
\text { vasodilators and have } \\
\text { antiaggregative action on } \\
\text { the endothelium } \\
\text { in neutrophils }\end{array}$ & $\begin{array}{l}\text { de Morais et al., } 2015 \text { [46]; } \\
\text { Paliwal et al., } 2017 \text { [52]; }\end{array}$ \\
\hline
\end{tabular}


Table 1. Cont.

\begin{tabular}{|c|c|c|c|c|c|}
\hline S. No. & $\begin{array}{l}\text { Microalgae } \\
\text { Compounds }\end{array}$ & Pigment & Microalgae Species & Activity on Human Health & Reference \\
\hline & & $\begin{array}{c}\gamma \text {-linoleic } \\
\text { acid (GLA) }\end{array}$ & $\begin{array}{l}\text { Anthrospira, } \\
\text { Chlorococcum sp., } \\
\text { Dunaliella primolecta, } \\
\text { Spirulina sp. }\end{array}$ & $\begin{array}{l}\text { Relieves from breast cancer, } \\
\text { skin allergies, alcoholism, } \\
\text { obesity, rheumatoid } \\
\text { arthritis, blood pressure, } \\
\text { heart diseases, } \\
\text { premenstrual syndrome, } \\
\text { sclerosis, hyperactivity } \\
\text { attention deficit disorder } \\
\text { (ADHD), diabetes-related } \\
\text { neural issues }\end{array}$ & $\begin{array}{l}\text { Koller et al., } 2014 \text { [64]; } \\
\text { Mourelle et al., } 2017 \text { [78] }\end{array}$ \\
\hline & & Linolenic acid & $\begin{array}{l}\text { Botryococcus braunii, } \\
\text { Chlorococcum sp., } \\
\text { Dunaliella primolecta, } \\
\text { Scenedesmus obliqus, } \\
\text { Tetraselmis suecica }\end{array}$ & $\begin{array}{l}\text { Anti-inflammatory, acne } \\
\text { reductive and } \\
\text { moisture retention }\end{array}$ & Day et al., 2009 [79] \\
\hline \multirow{3}{*}{5.} & \multirow{3}{*}{ Proteins } & Glycoprotein & $\begin{array}{c}\text { Alexandrium minutum, } \\
\text { Chlorella sp., } \\
\text { Dunaliella sp., } \\
\text { Schizochytrium sp., Spirulina }\end{array}$ & $\begin{array}{l}\text { Antihypertensive and } \\
\text { Angiotensin I inhibitory } \\
\text { activities, appetite } \\
\text { suppression and reduction } \\
\text { of LDL-cholesterol. It is } \\
\text { also used as dietary } \\
\text { supplements (tablets, } \\
\text { powder and paste) }\end{array}$ & $\begin{array}{c}\text { Andrade et al., } \\
2018 \text { [56]; Caporgno and } \\
\text { Mathys 2018 [50]; da Silva } \\
\text { Viz et al., } 2016 \text { [17]; Galasso } \\
\text { et al., } 2019 \text { [30]; Hempel } \\
\text { et al., 2011 [51]; Kim et al., } \\
\text { 2012 [80];Marquez-Escobar } \\
\text { et al., } 2018 \text { [81] }\end{array}$ \\
\hline & & Phycobiliprotein & Cyanobacteria & $\begin{array}{l}\text { Bio-sensor, neuroprotective, } \\
\text { anti-nephrolithe, } \\
\text { anti-hyperglycemic, } \\
\text { immunomodulatory and } \\
\text { hepatoprotective properties. } \\
\text { Used as fluorescent labels } \\
\text { in antibodies and receptors, } \\
\text { flow-cytometry, } \\
\text { immunohistochemistry }\end{array}$ & $\begin{array}{l}\text { Bhattacharjee } 2016 \text { [82]; } \\
\text { Paliwal et al., } 2017 \text { [52] }\end{array}$ \\
\hline & & $\begin{array}{l}\text { Recombinant } \\
\text { protein }\end{array}$ & $\begin{array}{l}\text { Chlamydomonas elipsoidea, } \\
\text { Chlamydomonas reinhardtii; }\end{array}$ & $\begin{array}{l}\text { Anemia treatment, wound } \\
\text { healing, anti-malarial } \\
\text { vaccines, antibody against } \\
\text { anthrax, Herpes simplex } \\
\text { virus, human papilloma } \\
\text { virus, white spot syndrome } \\
\text { virus, foot and mouth } \\
\text { disease virus, } \\
\text { immunotoxins against } \\
\text { B-cell lymphoma and } \\
\text { increase resistance to } \\
\text { UV-induced stress }\end{array}$ & $\begin{array}{c}\text { Brasil et al., } 2017 \text { [10]; } \\
\text { Hempel et al., } 2016 \text { [53]; } \\
\text { Specht et al., } 2010 \text { [55]; } \\
\text { http:/ / www.olson.com.br / } \\
\text { (accessed on } 15 \text { March 2021) }\end{array}$ \\
\hline 6. & Amino acid & $\begin{array}{l}\text { Mycosporine- } \\
\text { like amino } \\
\text { acid (MAA) }\end{array}$ & $\begin{array}{c}\text { Chlorella pyrenoidosa, Chlorella } \\
\text { vulgaris, Microcystis aeruginosa, } \\
\text { Nitzschia incerta }\end{array}$ & $\begin{array}{l}\text { Antioxidant properties, } \\
\text { prevents atherosclerosis, } \\
\text { cancer, coronary diseases } \\
\text { and used in photo-aging } \\
\text { protective formulations }\end{array}$ & $\begin{array}{l}\text { Gregory et al., } 2013 \text { [54]; } \\
\text { Kim et al., } 2011 \text { [83]; } \\
\text { Lawrence et al., } 2018 \text { [84] }\end{array}$ \\
\hline \multirow[b]{2}{*}{7.} & \multirow[b]{2}{*}{ Vitamins } & Vitamin A & $\begin{array}{l}\text { Chlorella sp., } \\
\text { Eisenia arborea, } \\
\text { P. cruentum }\end{array}$ & $\begin{array}{l}\text { Involved in vision, } \\
\text { reproduction, immune } \\
\text { function and cellular } \\
\text { communication }\end{array}$ & $\begin{array}{l}\text { Andrade et al., } 2018 \text { [56]; } \\
\text { Koyande et al., } 2019 \text { [14]; }\end{array}$ \\
\hline & & Vitamin B & $\begin{array}{l}\text { Chlorella, } \\
\text { Spirulina, } \\
\text { Pavlova, } \\
\text { Tetraselmis }\end{array}$ & $\begin{array}{l}\text { Anticancer activity, reduces } \\
\text { cholesterol, regeneration of } \\
\text { blood cells, DNA repair, } \\
\text { histone methylation, } \\
\text { preservation of skin and } \\
\text { mucous membranes and } \\
\text { cardiovascular disease }\end{array}$ & $\begin{array}{l}\text { Becker et al., } 2004 \text { [85]; } \\
\text { Delasoie et al., } 2018 \text { [86] }\end{array}$ \\
\hline
\end{tabular}


Table 1. Cont.

\begin{tabular}{|c|c|c|c|c|c|}
\hline S. No. & $\begin{array}{l}\text { Microalgae } \\
\text { Compounds }\end{array}$ & Pigment & Microalgae Species & Activity on Human Health & Reference \\
\hline & & Vitamin E & $\begin{array}{c}\text { Chaetoceros calcitrans, Dunaliella } \\
\text { tertiolecta, Nannochloropsis } \\
\text { oculata, Porphyridium cruentum } \\
\text { and Tetraselmis suecica }\end{array}$ & $\begin{array}{c}\text { Protects membrane lipids } \\
\text { from oxidative damage and } \\
\text { prevent coronary, } \\
\text { atherosclerosis as well as } \\
\text { neurodegenerative diseases. } \\
\text { Improves endothelial } \\
\text { function, vascular health } \\
\text { and inhibits prostate cancer } \\
\text { cell growth }\end{array}$ & $\begin{array}{c}\text { Bong et al., } 2013 \text { [60]; } \\
\text { Giammanco et al., } 2015 \text { [59] }\end{array}$ \\
\hline & & Vitamin $\mathrm{K}$ & Anabaena cylindrica & $\begin{array}{l}\text { Protect against toxic } \\
\text { pollutants, prevention of } \\
\text { chronic diseases }\end{array}$ & Tarento et al., 2018 [58] \\
\hline 8. & Sterols & $\begin{array}{l}\text { Brassicasterol } \\
\text { Stigmasterol } \\
\text { Phytosterols }\end{array}$ & $\begin{array}{c}\text { Chlorella vulgaris, Pavlova } \\
\text { lutheria, Nanochloropsis sp. BR2 } \\
\text { and Tetraselmis sp. M8 }\end{array}$ & $\begin{array}{l}\text { Anti-inflammatory and } \\
\text { anticancer activities, } \\
\text { stabilizes phospholipid } \\
\text { bilayers, reducing blood } \\
\text { cholesterol levels in hyper } \\
\text { and normocholesterolemic } \\
\text { people and inhibit colon } \\
\text { cancer development }\end{array}$ & $\begin{array}{l}\text { Ahmed et al., } 2015 \text { [63]; } \\
\text { Lopes et al., } 2013 \text { [61]; Luo } \\
\text { et al., } 2015 \text { [62] }\end{array}$ \\
\hline
\end{tabular}

\subsection{Sterols}

Phytosterols are structurally similar and functionally analogous to cholesterol with an additional alkyl group in the side chain of the sterol nucleus. They are used as additives in many food products and characterized by the presence of different phytosterols such as stigmasterol, sitosterol, and brassicasterol [20]. Sterols are essential constituents of cell membranes and play a key role in stabilizing phospholipid bilayers and in signal transduction as hormone precursors. These are crucial components of a healthy diet for reducing blood cholesterol levels in hyper and normocholesterolemic people and inhibiting colon cancer development [61]. Methanolic extracts of Chlorella vulgaris exhibited anticancer and anti-inflammation properties due to the presence of 2 delta $(5,7)$-sterols (ergosterol and 7-dehydroporiferasterol peroxide), 7-oxo-delta(5)-sterol (7-oxocholesterol), and 5,8 alphaepidioxy-delta(6)-sterol [62]. Pavlova lutheria, Nanochloropsis sp. (BR2), and Tetraselmis sp. (M8) are good phytosterol producers, especially Pavlova lutheria, with $5186 \mathrm{mg} / 100 \mathrm{~g}$. The minimal intake of 2 to $3 \mathrm{~g}_{\text {day }}{ }^{-1}$ promotes the smooth functioning of the heart, blood vessels, and minimizes lipoprotein [63].

\section{Therapeutical Function of Microalgae}

Microalgae and their extracts are an enormous and under-explored source of biologically active compound (Table 2).

\subsection{Antioxidant Activity}

Prooxidants are endobiotic or xenobiotic that induce oxidative stress either by generation of reactive oxygen species (ROS) or by inhibiting antioxidant systems situated in the inner mitochondrial membrane. Reactive oxygen species (ROS) produce intermediates such as superoxide anion $\left(\mathrm{O}_{2}{ }^{-}\right)$, singlet oxygen $\left({ }^{1} \mathrm{O}_{2}{ }^{-}\right)$, hydrogen peroxide $\left(\mathrm{H}_{2} \mathrm{O}_{2}\right)$, peroxyl (ROO), and hydroxyl radical (-OH), which are accumulated due to the imbalance in the equilibrium ratio of oxidant to antioxidant [12,87]. They are intruded upon as a result of smoking, unhealthy eating habits, exposure to sunlight, UV irradiation, X-rays, and gamma rays. ROS/Reactive nitrogen species (RNS) may lead to increased oxidative stress and are responsible for membrane lipid peroxidation, swelling and lysis of mitochondria, mutagenic actions, and post-translational protein modifications including various chronic diseases like diabetes mellitus, Alzheimer's, respiratory disorders, rheumatoid arthritis, cataracts, Parkinson's, cancer, as well as the aging process [88]. The antioxidants synthe- 
sized within the human body in vivo and incorporated by enzymatic and non-enzymatic pathways are called endogenous antioxidants. Antioxidants supplemented through ex-situ or external food supplements are called exogenous antioxidants/nutrient oxidants. They include bioflavonoids, carotenoids, vitamins (C and E), biometals, and omega-3 and omega6 fatty acids [73]. Increasing concern over oxidative stress-mediated diseases led to the identification of therapeutic approaches and herbal medicines derived from foods rich in natural antioxidants. Microalgae are well known for natural antioxidants because of their fast growth rate and production of multiple components in a single species. Algae contain several enzymatic antioxidants (superoxide dismutase (SOD), catalase (CAT), glutathione peroxidase (GPX), and peroxiredoxin (PrxR)) and non-enzymatic antioxidants (phenols, flavonoids, and alkaloids) that quench free radicals or rejuvenate antioxidants with the aid of reducing equivalents generated by photosynthetic processes [89]. The presence of conjugated double bonds or the presence of epoxy, acetyl, allene, or acetylene groups with carotenoids are responsible for antioxidant activity [56]. Antioxidants synthesized from microalgae (Butylated hydroxyanisole (BHA) and Butylated hydroxytoluene (BHT)) provide better protection when compared to synthetic antioxidants. Seven microalgal species viz Spirulina platensis, Nostoc sp., Anabaena oryzae, Anabaena flos aquae, Oscillatoria sp., Phormedium fragile, and Chlorella vulgaris were screened for antioxidant activity by 2,2Diphenyl-1-(2,4,6-trinitrophenyl)hydrazyl (DPPH) and 2'-azino-bis(3-ethylbenzothiazoline6-sulfonate)(ABTS) methods [90]. The antioxidant property of nine microalgae varied from 30.1 to $72.4 \%$ and 31.2 to $75.9 \%$ when compared with standard BHT antioxidant $(80.2 \%$ and $85.6 \%$ [ [90]. Astaxanthin suppresses oxidative injury by activating quinone oxidoreductase (NQO-1), glutathione-S-transferase-alpha1 (GST- $\alpha 1$ ), and heme oxygenase (HO-1) via the antioxidant responsive element (Nrf2-ARE) and nuclear factor erythroid-related factor 2 signaling pathway [68,91]. Chlorella sorokiniana contains $\beta$-carotene $\left(600 \mu \mathrm{g} \mathrm{g}^{-1}\right)$, $\alpha$ tocopherol $\left(112 \mu \mathrm{g} \mathrm{g}^{-1}\right)$ and lutein $\left(4300 \mu \mathrm{g} \mathrm{g}^{-1}\right)$, which possess high radical scavenging activity [92]. Lutein and $\beta$-carotene extracted from Chlorella sp. significantly inhibited cognitive disability that leads the way to Alzheimer's disease in rats [46]. A cocktail, i.e., $100 \mu \mathrm{g} \mathrm{mL}{ }^{-1}$ of Tetraselmis suecica hydroalcoholic extract (antheraxanthin, neoxanthin, carotenes, lutein, and violaxanthin) showed resistance to $30 \mathrm{mM}$ of $\mathrm{H}_{2} \mathrm{O}_{2}$ in human cells [71]. Phycobiliproteins extracted from Phormidium autumnale exhibited an antioxidant capacity of $274 \mu \mathrm{mol}$ Trolox $\mathrm{g}^{-1}$ of total dry biomass weight [93]. Sulfated polysaccharide extracted from $R$. reticulata is twice as potent as $\alpha$-tocopherol against superoxide anion $[74,94]$.

\subsection{Antimicrobial Activity}

Microalgae are a valuable source of antibiotics and show potent antimicrobial activity because of their ability to produce carbohydrates, proteins, lipids, halogenated hydrocarbons, phytosterols, monocyclic aromatic compounds, phenols, and polyketide products [46]. Lipid structure and other compounds such as $\alpha$-and $\beta$-ionone, $\beta$-cyclocitral, neophytadiene, and phytol are attributed to the antimicrobial action of microalgae extracts. Microalgal derived composites are used as adjuvants in fortified foods and fodder formulations to reinstate existing synthetic compounds of microbial origin.

\subsubsection{Antibacterial Activity}

The growing resistance of pathogenic bacteria for antibiotics with consequences on human health is of great concern. These bacteria contaminate foods and, in turn, infect humans causing several foodborne diseases like diarrhea [95]. Pratt was the pioneer who isolated chlorellin, a fatty acid mixture from Chlorella, which exhibited antibacterial activity against several Gram positive and Gram negative bacteria [96]. 'Parsiguine,' an antimicrobial compound isolated from Fischerella ambigua, showed a minimum inhibitory concentration (MIC) of $40 \mathrm{mg} / \mathrm{mL}$ and $20 \mathrm{mg} / \mathrm{mL}$ against S. epidermidis PTCC 1114 and C. krusei ATCC 44507 [97]. The extracts from algae paved a path to develop new drugs against bacterial infections, foodborne, and human pathogens. Microalgae antibacterial activity functions against many human pathogens such as Salmonella, Escherichia coli, 
Campylobacter, Pseudomonas, Shigella, and Staphylococcus, which can be attributed to the presence of monounsaturated and polyunsaturated fatty acids. These fatty acids possessing antibacterial activity can also impede bacterial fatty acid biosynthesis [98]. Algal fatty acids interfere with bacterial growth and cause harmful effects to the microorganisms, i.e., cell leakage, membrane damage, reduced nutrient uptake, and inhibit cellular respiration. Fatty acids with more than ten carbon atom induce bacterial protoplast lysis [99]. Gram (-) bacteria are more resistant than Gram (+) bacteria due to their complex membrane permeability and impenetrable cell wall. Methanol, benzene, petroleum ether, and hexane are the solvents used to extract antibacterial compounds from microalgae [100].

Microalgal species from different taxonomic groups contain mixed antibacterial fractions such as chlorellin, alpha-linolenic acid, polyunsaturated fatty acids, methanolic extracts, short-chain fatty acids, phycobiliproteins, exopolysaccharides, beta-ionone, and neophytadiene [101]. These fractions possess antibacterial property against numerous human bacteria, namely Eischerichia coli, Pseudomonasaeruginosa, Enterobacter aerogenes, Salmonella typhimurium, Klebsiella pneumonia, Vibriocholerae, and Proteus vulgaris [97,102]. Chlorophyceae and Bacillariophyceae are predominant and possess high antimicrobial activity compared to other classes of algae. Dunaliella sp., a green microalga isolated from wastewater streams, showed a higher bactericidal effect than its ecads. EPA, hexadecatrienoic acid (HTA) and palmitoleic acid (PA) from Chlorococcum strain HS-101, Dunaliella primolecta, and Phaeodactylum tricornutum (diatom) showed potent bacteriostatic activity against methicillinresistant Staphylococcus aureus (MRSA), which is highly resistant to conventional antibiotics and is an increased concern in healthcare institutions worldwide [103]. Decadienal, microalgae-derived oxylipins exhibit strong antibacterial activity against Pfeiffer'sbacillus $\left(\mathrm{IC}_{50}-1.9 \mu \mathrm{g} / \mathrm{mL}\right)$ and methicillin-resistant Staphylococcus aureus $\left(\mathrm{IC}_{50}-7.8 \mu \mathrm{g} / \mathrm{mL}\right)$. Further, it impairs the production of different bacteria such as Eischerichia coli, Pseudomonas aeruginosa, Aeromonas hydrophila, Staphylococcus epidermidis, Photobacterium phosphoreum, Planococcus citreus, and Micrococcus luteus $[89,98]$. Short-chain fatty acids from H. pluvialis showed antibacterial activity against E. coli, whereas long-chain fatty acids from S. obliquus showed the same against Staphylococcus aureus [104]. S. grantiana and O. sancta ethanolic and methanolic extracts exhibited antibacterial activity against human pathogens, i.e., E. coli, P. vulgaris, and P. mirabilis with an inhibition zone of 9,10 , and $9 \mathrm{~mm}$, respectively [105]. Methanol extracts of Dunaliella salina and Pseudokirchneriella subcapitata with MICs ranging from $1.4 \times 10^{9}$ to $2.2 \times 10^{10}$ cells $/ \mathrm{mL}$ showed antimicrobial activity against external otitis (inflammation around the auditory canal and auricle) and indicate the evolution of S. aureus, P. aeruginosa, E. coli, and Klebsiella sp. [106]. Polysaccharides can act as surfactants and also modify bacterial morphology [107]. Microalgal polysaccharides act similar to E. coli polysaccharides and can inhibit bacterial adhesion and aggregation properties.

\subsubsection{Antiviral Activity}

Viruses are the smallest infectious agents for leading death rates globally. Preventing the invasion or synthesis of viral components is ambiguous as they have a deleterious impact on the host system. Although several antiviral drugs originated from plant secondary metabolites, mammals, and synthetic chemicals, drug-resistant mutations are continually occurring. Microalgae have gained renowned recognition as potential sources of antiviral agents in conjunction with the promotion of blue technology [108]. In antiviral compounds, microalgae predominate and cyanobacteria are a potential source of antiviral agents on an industrial scale [109]. Polysaccharides isolated from G. cartilagenium were the first antiviral compounds to safeguard egg embryos from mumps and flu viruses [110]. Herpes simplex virus (HSV1/HSV2) is a prevailing contagious disease, and around 30\% of the global population is affected by genital and oral herpes. Several studies documented that marine polysaccharides present a wide antiviral spectrum against enveloped viruses. Spirulan, a sulfated polysaccharide isolated from Spirulina platensis, demonstrated 
good antiviral activity against human immunodeficiency virus (HIV1) and herpes simplex virus (HSV1) [111].

Acyclovir ${ }^{\circledR}$, an antiviral compound isolated from Dunaliella sp., also deactivates the viral infections of HSV and HIV-1. Higher sulfate content induces higher antiviral activity, and the inhibitory effect arises by blocking the receptor sites of viral glycoprotein [74]. Polysaccharides (PS) isolated from A. platensis, R. reticulate, Porphyridium sp., G. impudicum, and C. polykrikoides are the prominent microalga exhibiting antiviral properties against innumerable viruses like Human alphaherpesvirus 3 (HHV-3), Herpes simplex virus (HSV1/HSV2), Human beta herpesvirus, murine leukemia virus (MuLV), Flu-A viruses, Hepatitis B virus (HBV), Encephalomyocarditis virus, Flu-A and B, viral hemorrhagic septicemia virus (VHSV), measles, African swine fever virus (ASFV), vaccinia virus (VACV), mumps, vesicular stomatitis virus (VSV), and respiratory syncytial virus (RSV-A\& B) [101,112-115]. Cyanovirin, a potential protein moiety produced by Nostoc species, showed promising effects in curing human influenza A and HIV [82]. The Algevir technology expressed an antigenic protein called ZK from Schizochytrium sp. in the Zika virus (ZIKV) glycoprotein envelope and displayed substantial humoral responses to those caused by subcutaneous immunization at greater magnitudes upon oral administration [81]. Extracted from Gyrodinium impudicum, sulfated polysaccharide p-KG03 demonstrated strong efficacy against the encephalomyocarditis RNA virus (EMCV) relative to current medicines [80]. Polysaccharide (TK V3) and exopolysaccharide from A. platensis and P. purpureum were shown to be successful against Vaccinia and Ectromelia orthopoxvirus with $\mathrm{IC}_{50}$ values ( 0.78 and $0.65 \mathrm{mg} / \mathrm{mL}$ ) when examined with HEp-2 and Vero C1008 cells lines [116]. Naviculan isolated from diatom $N$. directa and A1/A2 from C. polykrikoides showed strong antiviral activity against contagious diseases like HIV1, HSV1, and type A flu viruses [117]. Carrageenan lozenges are used for treating patients with sore throat and carrageenan pills are particularly potent against HRV1a HRV8, influenzavirus A H1N1n, Coxsackievirus A10, and human coronavirus (hCoV) OC43 [72]. Similar studies were carried out by Graf et al. for treating rhinitis and sinusitis caused by human rhinovirus 1a and human coronavirus OC43 [118]. The viral hemorrhagic septicemia virus (VHSV) affects more than 50 species of commercially important freshwater and marine fish, including salmonid fish. Nevertheless, fewer studies were conducted on the antiviral properties of microalgae.

\subsubsection{Antifungal Activity}

Fungal contagions were mostly due to intensive chemotherapy regimens that depress the patient's immune system, organ transplantation, and spread of prevalent diseases [119]. Screening of microalgae for antifungal compounds began far beyond antibacterial activity. Aspergillosis induced by Aspergillus sp. and candidemia caused by Candida $s p$. has been increasing exuberantly since ancient periods [120,121]. The formulation of new drugs and antifungal activity varies widely depending on microalgal species. Marine microalgae (e.g., Chaetoceros sp.) have more capability in developing novel antifungal compounds compared to fresh habitats [102]. Several antifungal compounds such as polysaccharides, organic solvent extracts, polyethers, and lipid fractions isolated from green (H. pluvialis, Chlorella vulgaris and Scenedesmus sp.) and red microalgae (Porphyridium sp. and $R$. reticulata), Bacillariophytes, and dinoflagellates show activity against microorganisms such as A. fumigatus, A. niger, Penicillium sp., Saccharomycessp., Candida sp., Microsporum sp., and E. floccosum [122,123]. Gambieric acid, a potent antifungal agent with polycyclic ether isolated from Gambierdiscus toxicus, acts against molds and dermatophytes while the diatom Thalassiothrix frauenfeldii was involved against active yeasts [124]. Amphidinol, a potent antifungal agent isolated from Amphidinium klebsii, targets fungi membrane, mainly the ergosterol biosynthetic pathway [125]. Pigments produced by $H$. karadagensis showed antifungal activity against C. maritima, D. salina, and Lulworthia sp. responsible for biological fouling [126]. Organic extracts from C. lauderi, G. toxicus, and C. vulgaris inhibit Aspergillus fumigatus, a toxin-producing fungus that contaminates seafood of marine bivalves [127]. 


\subsection{Anticancer Activity}

Cancer is the single most serious disorder causing irregular cell growth that has the ability to infiltrate other body parts. A lump, irregular bleeding, excessive coughing, weight loss, and a decrease in bowel movements are potential symptoms. Human beings are affected by over 100 types of diseases, the bulk of which are due to hereditary abnormalities, i.e., environmental and lifestyle causes (90-95\%), and the remaining $5-10 \%$ is due to inherited genetics [128]. Chemotherapy is the most promising anticancer approach aimed at reducing mortality by delaying the carcinogenesis process. Several enzymatic and non-enzymatic antioxidants from natural sources suppress tumorgenesis by inhibiting tumor cell protease activity, fostering cell division, triggering cell death, and immunomodulations [83]. Chinery et al. reported that the combined effect of antineoplastic agents and antioxidants helps in remission of colon cancer [129]. Cyanobacteria are an abundant source of natural foods, and their medicinal value was recognized at the beginning of the 15th century when Nostoc strains were used to treat malignant tumors, arthritis, and fistula. Anabaena and Nostoc sp. are important cyanobacteria that produce over 120 natural products with potent activity against several cancer-causing agents [130]. Chlorophyllin, a derivative of chlorophyll, acts against HCT1 16 human colon cancer cells because of its high effectiveness as a chemo-preventive agent [64]. Aqueous extract of Nostoc muscorum showed the highest anticancer activity in humans against Ehrlich cell $(87.25 \%)$ and hepatocellular carcinoma (89.4\%) [90]. This is attributed to the high content of phycobiliproteins, polysaccharides, and polyphenols, which induced programmed cell death of tumor cells. Bioactive compounds dragonamide A-E and dragomabin isolated from cyanobacterium Lyngbya sp. exhibited in vivo activity against leishmaniasis. Moore's group isolated twenty-six cryptophycin from Nostoc sp. GSV 224, of which cryptophycin 52 was reported to be successful in lab trials for treating ovarian carcinoma and alveoli cancers [131]. C-phycocyanin, an aqueous extract of red algae, exhibits antiproliferation inducing apoptosis [132]. $\beta-(1,3)$-glucan, an active immunostimulator from C. vulgaris, is used as a potential antitumor agent [133]. Sulfated polysaccharides isolated from P. cruentum exhibited intense antitumor activity in rhodent peritoneum by hindering cancer cell progression and increasing the spleen and thymus indexes as well as boosting the immune system [134]. Exopolysaccharides of Porphyridium sp. retarded neoplasia, and its biomass in rats prevented the growth of colon cancer [135]. Fewer reports supported that gastric cancer can be treated using microalgae-derived peptides [136]. Vitamin B12, isolated from marine algae, is used as an encapsulating agent for anti-cancer drugs and plays a vital role in histone methylation, DNA synthesis, and the regeneration of blood cells. Cobalmin and folate extracted from diatomous microalgae with high proportions lower the risk of breast cancer [86].

\subsection{Anti-Inflammatory}

Inflammation is a cell or tissue's biological reaction to harmful factors, such as pathogenic agents, pollutants, weakened cell, and irritants, as well as a defensive response containing skin cells, blood cells and molecular mediators [137]. Inflammation normally occurs in heat, pain, swelling, and loss of control at the site of infection, but diabetes, obesity, renal, cardiovascular, and neurodegenerative disorders may be caused by chronic inflammation [138]. Oxidative stress is the predominant factor responsible for several inflammatory responses inducing mitochondrial dysfunction and beta-amyloid aggregation [139]. Besides, ROS generated in brain tissue also causes neurodegeneration, cellular death, and memory loss by modulating synaptic and non-synaptic communication between neurons [140]. Oral uptake/consumption of anti-inflammatory compounds revitalizes body immunity and aids in the healing process. Microalgae produce several antiinflammatory metabolites such as carotenoids, PUFAs, phycobiliproteins, carbohydrates, and sulfurized polysaccharides that suppress chronic inflammation and exert a protective function when consumed as food or used as pharmaceutical supplements [141,142]. Because of the metabolites mentioned above, microalgae are being considered in regenera- 
tive medicine for developing tissue scaffolds, especially in patients with skin burns [143]. The PUFAs ( $\omega 3$ and $\omega 6$ fatty acids), especially arachidonic, docosahexaenoic, and eicosapentaenoic acids, are mainly involved in treating rheumatoid arthritis and dermatitis. Anti-inflammatory effects of DHA are prominent in developing breast milk, human fetus, and act against colon and breast cancer [144]. DHA and EPA produced from Schizochytrium species are widely used for nourishment in women in maternity and cardiac patients. DHA intake as a subsidiary food modulated fibrillar oligomers in transgenic APP/PS1 rat brains by blocking $\beta$ eta-amyloid aggregation [77]. Docosapentaenoic acid (DPA) extracted from Schizochytrium sp. inhibits cytokines (IL-1 and TNF- $\alpha$ ) in peripheral blood mononuclear cells (PMBC) of humans [145]. Astaxanthin produced from Haematococcus pluvialis had more remarkable inhibitory effects on lipopolysaccharide-induced inflammation and anti-inflammatory action than prednisolone [146]. ASX could prevent lipopolysaccharideinduced acute respiratory distress syndrome (ARDS) and sepsis by suppressing the signaling pathway of MPAK/NF-KB and decreasing pro-inflammatory cytokine level [65]. It also showed protective effects against lung injury, repressed alveolar wall swelling, myeloperoxidase activity, and attenuation of number of pulmonary alveoli in lung tissues [32]. Research conducted by Chang et al. reported that astaxanthin defends nerve cells against $A \beta 25-35$-induced apoptosis by inhibiting radical oxidative destruction, Bax expression, nuclear transcription factor-kB (NFkB), and P-38 MAP kinase dephosphorylation (mitogen-activated protein) [66]. In a clinical trial performed on healthy young women, a daily dosage of two milligrams of astaxanthin for two months lowered inflammatory cytokines, C-reactive protein, and also decreased ROS production by the transcription factors regulating nuclear factor (NF- $\mathrm{KB}$ ) and activator protein (AP-1) [67]. Algal metabolites produce various pro-inflammatory mediators, and its mechanism includes enzyme modulation (prostaglandin-endoperoxide synthase, phospholipase A2, and NO synthase), modulating cellular processes, and intervening with nuclear factor $\mathrm{kB}(\mathrm{NF}-\mathrm{kB})$ and the mitogen-activated protein kinase pathways $[147,148]$. Inhibitory effects and reduced production of nitric oxide synthase and prostaglandins in phagocytic cells were shown by Fucoidan, a sulfated polysaccharide isolated from brown algae [149]. Among the pigments, fucoxanthin isolated from Bacillariophyceae is capable of eliciting metastasis in humans, and phycobiliproteins from cyanobacteria can inhibit histamine release [150]. Spirulan isolated from A. platensis showed similar properties to that of glycosaminoglycans (GAG), present in animals with bioactivities involved in human physiological and pathological responses [151]. Besides oxidative stress, exopolysaccharides from Porphyridiumcruentum enhanced immunostimulating activity in vitro and inhibited membrane peroxidation [134] Sulfated polysaccharides possessing anti-inflammatory properties can be used in dermal treatments by blocking the polymorphonuclear leukocytes stimulations. Sulfolipids isolated from Scenedesmus rubescens, Scenedesmus acuminatus, and Phaeodactylum tricornutum are effective in inhibiting alpha-glucosidase, glutaminyl-peptide cyclotransferase, and telomerase activities [73]. In addition, natural ASX, with its proven anti-inflammatory and anti-oxidant activity backed by multiple preclinical and human trials and with its extraordinary safety profile, can be one of the most promising candidates to be tried against COVID-19 [32].

\subsection{Antiaging}

Bioactive compounds of micro- and macroalgae are compounds of interest in cosmetics and skin care products. They accelerate pigmentation, skin moisture, prevent blemishes, help seborrhea, atopic dermatitis, and skin carcinogenesis [50]. Fujimura's group in 2002 first identified that aqueous extracts of Fucus vesiculosus (Bladder wrack) improved skin thickness and cheek elasticity. Algal extracts increase the transcriptional level and expression of involucrin (INV), loricrin (LOR), transglutaminase-1 (TGM-1), filaggrin (FLG), and type 1 pro-collagen, which are the major markers for skin barrier function [152]. Mycosporine amino acids (MAA) and polysaccharides are widely employed in skin photoaging, and their efficiency was tested in HeLa cervical adenocarcinoma and 
B16-F1 murine skin melanoma of human cell lines [84]. MAAs have high efficiency in absorbing UV radiation (310-360 $\mathrm{nm}$ ) with molar absorptivity ranging from 2.8 to $5.0 \times 10^{4} \mathrm{M}^{-1} \mathrm{~cm}^{-1}$ [36]. Pentapharm (Basel, Switzerland), Blue Retinol ${ }^{\mathrm{TM}}$, Protulines, Exsymol S.A.M., (Monaco, Europe), and Helioguard ${ }^{\circledR} 365$ and SILIDINE ${ }^{\circledR}$ (Greentech, New Jersey, USA) are popular anti-aging skin products extracted from Nannochloropsis oculata, Porphyridium cruentum, and Arthrospira sp. [78]. Solazyme Inc. (San Francisco, CA, USA) and Terravia Holdings, Inc. (San Francisco, CA, USA) combined Parachlorella exopolysaccharides with Chlorella biomass and launched Golden Chlorella ${ }^{\mathrm{TM}}$ and AlgaPür ${ }^{\mathrm{TM}}$ algae oils that claim to deliver strong cosmetic benefits to the skin and hair [153].

\subsection{Other Activities}

Hypertension, including diabetes, kidney failure, stroke, and coronary diseases, is one of the leading risk factors for many chronic illnesses. Blood pressure in the human body is regulated by the angiotensin I conversion enzyme (ACE) found in the renin-angiotensinaldosterone system [154]. Captopril, lisinopril, and enalapril are commercially available synthetic ACE inhibitors that are used for treating hypertension. This showed numerous side effects such as coughing, dizziness, fatigue, headaches, and angioedema [155]. Widely used microalgae to produce ACE-inhibitory peptides are Chlorella vulgaris, Nannochloropsis oculata, C. ellipsiodea, and Arthrospira platensis. Dermochlorella DG, a product derived from Chlorella vulgaris and Arthrospira proteins, activates collagen synthesis, reduces striae distensae, vascular lesions, and also acts as skin resurfacing agent [11]. A purified peptide sequence isolated from C. vulgaris (Val-Glu-Cys-Tyr-Gly-Pro-Asn-Arg-Pro-Gln-Phe) and C. ellipsoidea (Val-Glu-Gly-Tyr) showed $\mathrm{IC}_{50}$ values of $29.6 \mu \mathrm{M}$ and $128.4 \mu \mathrm{M}$ when administered orally [156]. Similarly, the peptide sequence (Gly-Met-Asn-Asn-Leu-Thr-Pro and Leu-Glu-Gln) from N. oculata exhibited ACE-inhibitory activity of $123 \mu \mathrm{M}$ and $173 \mu \mathrm{M}$, respectively [157]. These peptide sequences bind to $\mathrm{C}$ - and $\mathrm{N}$-terminal active sites of ACE and block Angiotensin II production and prevent organ damage. Nanofibrils extracted from A. platensis could be used as an extracellular matrix for treating spinal cord injuries by culturing stem cells [158]. Spirulan isolated from A. platensis exhibits anti-thrombogenic properties by interfering with the blood coagulation-fibrinolytic system [159]. Aeruginosins and depsipeptides isolated from Microcystis aeruginosa and other microalgaeshow inhibitory effects against plasmin, thrombin, trypsin, and chymotrypsin [41]. Spriulina extract $(250 \mathrm{mg})$ plus Zinc $(2 \mathrm{mg})$ twice daily helps with the detoxification of heavy metals like Arsenic [160].

Table 2. Biological extracts and therapeutic applications of different microalgal species against human pathogens.

\begin{tabular}{|c|c|c|c|c|}
\hline \multicolumn{5}{|c|}{ Antibacterial Activity } \\
\hline S. No. & Microalgae species & Compound/Fraction & Targeted Microorganism & References \\
\hline 1. & $\begin{array}{l}\text { Bacillariophyceae and } \\
\text { Chrysophyceae }\end{array}$ & $\begin{array}{l}\text { Methanolic extracts, lysed cells, } \\
\text { phycobiliproteins, beta-ionone } \\
\text { and neophytadiene }\end{array}$ & $\begin{array}{c}\text { Escherichia coli, Pseudomonas } \\
\text { aeruginosa, Salmonella typhimurium, } \\
\text { Enterobacter aerogenes, Klebsiella } \\
\text { pneumoniae, Vibrio cholera and } \\
\text { Proteus vulgaris }\end{array}$ & $\begin{array}{c}\text { Cannell et al., } 1988 \text { [100]; Falaise } \\
\text { et al., } 2016 \text { [101]; Mudimu et al., } \\
2014 \text { [102]; Najdenski et al., } \\
\text { 2013 [97] }\end{array}$ \\
\hline 2. & Chlorella sp. & Chlorellin & $\begin{array}{l}\text { Gram-positive }(\mathrm{G}+) \text { and } \\
\text { Gram-negative }(\mathrm{G}-) \text { bacteria }\end{array}$ & Pratt et al., 1944 [96] \\
\hline 3. & Fischerella ambigua & Parsiguine & $\begin{array}{c}\text { S. epidermidis PTCC } 1114 \text { and C. } \\
\text { krusei ATCC } 44507\end{array}$ & Najdenski et al., 2013 [97] \\
\hline 4. & $\begin{array}{l}\text { Chlorococcum strain } \\
\text { HS-101, Dunaliella } \\
\text { primolecta, } \\
\text { Phaeodactylum } \\
\text { tricornutum }\end{array}$ & $\begin{array}{c}\text { Eicosapentaenoic acid (EPA), } \\
\text { hexadecatrienoic acid (HTA) and } \\
\text { palmitoleic acid (PA) }\end{array}$ & $\begin{array}{l}\text { Methicillin-resistant } S \text {. aureus } \\
\text { (MRSA), B. subtilis, Bacillus cereus, } \\
\text { S. aureus, Enterobacter aerogenes }\end{array}$ & Desbois et al., 2008 [103] \\
\hline
\end{tabular}


Table 2. Cont.

\begin{tabular}{|c|c|c|c|c|}
\hline \multicolumn{5}{|c|}{ Antibacterial Activity } \\
\hline S. No. & Microalgae species & Compound/Fraction & Targeted Microorganism & References \\
\hline 5. & Euglena viridis & Organic solvent extracts & $\begin{array}{c}\text { Edwardsiella tarda, Aeromonas } \\
\text { hydrophila, Pseudomonas tarda } \\
\text { Pseudomonas fluorescens, } \\
\text { Pseudomonas aeruginosa, } \\
\text { Vibrio alginolyticus putida, } \\
\text { V. anguillarum, Vibrio alginolyticus, } \\
\text { Vibrio anguillarum } \\
\text { Vibrio harveyi, fluvialis, } \\
\text { Vibrio parahaemolyticus }\end{array}$ & Das et al., 2005 [161] \\
\hline 6. & $\begin{array}{l}\text { Scenedesmus obliquus, } \\
\text { Haematococcus pluvialis }\end{array}$ & Fatty acids & E. coli and S. aureus & $\begin{array}{l}\text { Rodríguez-Meizoso et al., } \\
2010 \text { [104] }\end{array}$ \\
\hline 7. & Marine microalgae & Decadienal & $\begin{array}{l}\text { Human pathogens MRSA and } \\
\text { Haemophilus influenza }\end{array}$ & $\begin{array}{c}\text { Mostafa et al., } 2012 \text { [89]; Smith } \\
\text { et al., } 2010 \text { [98] }\end{array}$ \\
\hline 8. & $\begin{array}{l}\text { Spirogyra grantiana } \\
\text { and Oscillatoria sancta }\end{array}$ & Ethanolic and methanolic extract & E. coli, P. vulgaris and P. mirabilis & Prakash et al., 2011 [105] \\
\hline 9. & $\begin{array}{l}\text { Dunaliella salina and } \\
\text { Pseudokirchneriella } \\
\text { subcapitata }\end{array}$ & Methanolic extract & $\begin{array}{c}\text { S. aureus, P. aeruginosa, Escherichia coli } \\
\text { and Klebsiella sp. }\end{array}$ & Pane et al., 2015 [106] \\
\hline 10. & $\begin{array}{l}\text { Porphyridium } \\
\text { aerugineum }\end{array}$ & Phycobiliproteins & S. aureus, B. subtilis, S. pyogenes & Shannon et al., 2016 [95] \\
\hline \multicolumn{5}{|c|}{ Antifungal Activity } \\
\hline S. No. & Microalgae species & Compound/Fraction & Targeted microorganism & References \\
\hline 1. & $\begin{array}{c}\text { Chaetoceros sp., } \\
\text { Chlorella vulgaris, } \\
\text { Haematococcus } \\
\text { pluvialis, Porphyridium } \\
\text { purpureum, Rhodella } \\
\text { reticulata, Scenedesmus } \\
\text { quadricauda }\end{array}$ & $\begin{array}{l}\text { Polysaccharides, organic solvent } \\
\text { extracts, pigments and } \\
\text { lipid fractions }\end{array}$ & $\begin{array}{c}\text { A. fumigatus, A. niger, Penicillium sp., } \\
\text { C. albicans, C. neoformans, S. cerevisiae, } \\
\text { Microsporum sp., E. floccosum and } \\
\text { T. mentagrophytes }\end{array}$ & $\begin{array}{l}\text { Gueho et al., } 1977 \text { [123]; } \\
\text { Mudimu et al., } 2014 \text { [102]; } \\
\text { Washida et al., } 2006 \text { [122]; }\end{array}$ \\
\hline 2. & $\begin{array}{l}\text { Gambierdiscus toxicus, } \\
\text { Thalassiothrix } \\
\text { frauenfeldii }\end{array}$ & Gambieric acid & $\begin{array}{c}\text { Penicillium, Aspergillus oryzae, } \\
\text { Penicillium chrysogenum citrinum, } \\
\text { Variotii paecilomyces, } \\
\text { T. Mentagrophytes }\end{array}$ & Walter and Mahesh 2000 [124] \\
\hline 3. & $\begin{array}{l}\text { Chlorococcum humicola, } \\
\text { Porphyridium } \\
\text { aerugineum }\end{array}$ & $\begin{array}{l}\text { Beta-carotene, chlorophyll-a } \\
\text { and b }\end{array}$ & C. albicans, A. flavus and A. niger & Bhagavathy et al., 2011 [162] \\
\hline 4. & Amphidinium klebsii & Polyols: karatungiols A(1) & A. niger & Ghannoum et al., 1999 [125] \\
\hline 5. & Haslea. karadagensis & Pigments & $\begin{array}{l}\text { Corollospora maritima, Dendryphiella } \\
\text { salina and Lulworthia sp. }\end{array}$ & Gastineau et al., 2012 [126] \\
\hline 6. & $\begin{array}{l}\text { Chaetoceros lauderi, } \\
\text { Chlorella vulgaris and } \\
\text { Gambierdiscus toxicus }\end{array}$ & Organic extracts & Aspergillus fumigatus & Ghasemi et al., 2007 [127] \\
\hline 7. & $\begin{array}{l}\text { Scenedesmus } \\
\text { quadricauda }\end{array}$ & Organic solvent extracts & $\begin{array}{c}\text { C. albicans, S. cerevisiae, } A \text {. flavus, } A . \\
\text { niger, P. herquei, A. brassicae, } \\
\text { F. moniliforme, } \\
\text { Helminthosporium sp. }\end{array}$ & Alangaden 2011 [119] \\
\hline \multicolumn{5}{|c|}{ Antiviral Activity } \\
\hline S. No. & Microalgae species & Compound/Fraction & Targeted virus & References \\
\hline 1. & Gelidium cartilagenium & Polysaccharides & Influenza B and mumps viruses & Gerber et al., 1950 \\
\hline 2. & $\begin{array}{l}\text { Dunaliella sp., } \\
\text { Spirulina platensis }\end{array}$ & Acyclovir $^{\circledR}$, Spirulan & $\begin{array}{c}\text { Type } 1 \text { Herpes simplex virus (HSV-1) } \\
\text { and Type } 1 \text { Human } \\
\text { Immunodeficiency Virus (HIV-1) }\end{array}$ & $\begin{array}{l}\text { Hayashi et al., } 1996 \text { [111]; } \\
\text { Raposo et al., } 2014 \text { [74] }\end{array}$ \\
\hline
\end{tabular}


Table 2. Cont.

\begin{tabular}{|c|c|c|c|c|}
\hline \multicolumn{5}{|c|}{ Antibacterial Activity } \\
\hline S. No. & Microalgae species & Compound/Fraction & Targeted Microorganism & References \\
\hline 3. & $\begin{array}{l}\text { Arthrospira platensis, } \\
\text { Cochlodinium } \\
\text { polykrikoides, } \\
\text { Gymnodinium } \\
\text { impudicum } \\
\text { Porphyridium sp., and } \\
\text { Rhodomonas reticulate }\end{array}$ & Polysaccharides & $\begin{array}{c}\text { Varicella zoster viruses (VZV), human } \\
\text { cytomegalovirus (HCMV), murine } \\
\text { leukemia virus (MuLV), Flu-A } \\
\text { viruses, Hepatitis B virus (HBV); } \\
\text { viral hemorrhagic septicemia virus } \\
\text { (VHSV); African swine fever virus } \\
\text { (ASFV), vaccinia virus (VACV), } \\
\text { vesicular stomatitis virus (VSV), } \\
\text { Encephalomyocarditis virus, Flu-A } \\
\text { and Flu-B, respiratory syncytial virus } \\
\text { types A (RSV-A) and B (RSV-B), } \\
\text { measles, mumps }\end{array}$ & $\begin{array}{c}\text { Falaise et al., } 2016 \text { [101]; } \\
\text { Huleihel et al., } 2002 \text { [114]; } \\
\text { Raposo et al., } 2014 \text { [74]; } \\
\text { Santoyo et al., } 2011 \text { [113]; } \\
\text { Silva et al., 2018 [112]; } \\
\text { Talyshinsky et al., } 2002 \text { [115] }\end{array}$ \\
\hline 4. & Gyrodinium impudicum & Sulphated polysaccharide & $\begin{array}{c}\text { Encephalomyocarditis RNA } \\
\text { virus (EMCV) }\end{array}$ & $\begin{array}{l}\text { Huheihel et al., } 2002 \text { [114]; } \\
\text { Kim et al., } 2012 \text { [80] }\end{array}$ \\
\hline 5. & $\begin{array}{l}\text { Arthrospira platensis, } \\
\text { Porphyridium. } \\
\text { purpureum }\end{array}$ & $\begin{array}{l}\text { Polysaccharide TK-V3 } \\
\text { Exopolysaccharides }\end{array}$ & $\begin{array}{l}\text { Vaccinia and Ectromelia } \\
\text { orthopoxvirus }\end{array}$ & Radonic et al., 2010 [116] \\
\hline 6. & $\begin{array}{l}\text { Cochlodinium } \\
\text { polykrikoides Navicula } \\
\text { directa }\end{array}$ & Naviculan & $\begin{array}{l}\text { HIV-1,HSV-1 and influenza virus } \\
\text { type A (IFV-A) }\end{array}$ & Lee et al., 2006 [117] \\
\hline 7. & $\begin{array}{l}\text { Chlorella autotrophica, } \\
\text { Dunaliella tertiolecta, } \\
\text { Ellipsoidon sp., Isochry- } \\
\text { sis galbana var. Tiso and } \\
\text { Porphyridium cruentum }\end{array}$ & Endocellular extracts & $\begin{array}{l}\text { Inhibited the viral infection of } \\
\text { epithelioma papulosum cyprinid } \\
\text { (EPC) cells }\end{array}$ & $\begin{array}{l}\text { Graf et al., } 2018 \text { [118]; } \\
\text { Talyshinsky et al., } 2002 \text { [115] }\end{array}$ \\
\hline 8. & $\begin{array}{l}\text { Dunaliella salina, } \\
\text { Haematococcus pluvialis }\end{array}$ & $\begin{array}{c}\text { Short chain fatty acids, } \beta \text {-ionone, } \\
\text { phytol, } \\
\text { neophytadiene, palmitic and } \\
\alpha \text {-linolenic acids }\end{array}$ & Herpes simplex virus type 1 (HSV-1) & Santoyo et al., 2011 [113] \\
\hline 9. & Cochlodiniumpolykrikoides & $\begin{array}{l}\text { Extracellular sulphated } \\
\text { polysaccharides: } \\
\text { A1 and A2 }\end{array}$ & $\begin{array}{c}\text { Flu-A and B-Flu, } \\
\text { Syncytial breathing } \\
\text { Forms of Viruses A (RSV-A) } \\
\text { A, and B (RSV-B), } \\
\text { HIV-1, HSV-1, } \\
\text { Parainfluenza } \\
\text { type 2(PFluV-2) }\end{array}$ & $\begin{array}{l}\text { Hasui et al., } 1995 \text { [163]; } \\
\text { Morokutti-Kurz et al., } 2017 \text { [72]; }\end{array}$ \\
\hline \multicolumn{5}{|c|}{ Antioxidant Activity } \\
\hline S. No. & Microalgae species & Compound/Fraction & Application & References \\
\hline 1. & $\begin{array}{c}\text { Anabaena flos aquae, } \\
\text { Anabaena oryzae, } \\
\text { Nostoc humifusum, } \\
\text { Chlorella vulgaris, } \\
\text { Nostoc muscorum, } \\
\text { Oscillatoria sp., } \\
\text { Phormedium fragile, } \\
\text { Spirulina platensis, and } \\
\text { Wollea saccata }\end{array}$ & Algal extracts & $\begin{array}{c}\text { Antioxidant activity is higher } \\
\text { compared to standard Butylated } \\
\text { hydroxytoluene (BHT) antioxidant }\end{array}$ & $\begin{array}{l}\text { Barkia et al., } 2019 \text { [12]; } \\
\text { Kattappagari et al., } 2015 \text { [87]; } \\
\text { Lawrence et al., } 2018 \text { [84]; } \\
\text { Shanab et al., } 2012 \text { [90] }\end{array}$ \\
\hline 2. & $\begin{array}{l}\text { Chlorella sorokiniana } \\
\text { Sanropus androgynous }\end{array}$ & $\begin{array}{l}\beta \text {-carotene, } \alpha \text { tocopherol, } \\
\text { Chlorophyll and lutein }\end{array}$ & High radical scavenging activity & $\begin{array}{l}\text { de Morais et al., } 2015 \text { [46]; } \\
\text { Matsukawa et al., } 2000 \text { [92]; } \\
\text { Suparmi et al., } 2016 \text { [91]; }\end{array}$ \\
\hline 3. & Porphyridium cruentum & Exopolysaccharides & $\begin{array}{l}\text { Scavenging hydroxyl, superoxide } \\
\text { anion, and DPPH free radicals }\end{array}$ & $\begin{array}{l}\text { Li et al., } 2007 \text { [164]; } \\
\text { Wu et al., } 2014 \text { [68] }\end{array}$ \\
\hline 4. & $\begin{array}{l}\text { Dunaliella sp., } \\
\text { Rhodella reticulata }\end{array}$ & $\begin{array}{l}\text { Glutathione, Sulfated } \\
\text { polysaccharides }\end{array}$ & $\begin{array}{l}\text { Scavenges ROS and prevents } \\
\text { cellular damage }\end{array}$ & $\begin{array}{c}\text { de Jesus Raposo et al., } 2013 \text { [94]; } \\
\text { Li et al., } 2007 \text { [164]; } \\
\text { Mostafa } 2012 \text { [89]; } \\
\text { Raposo et al., } 2014 \text { [74] }\end{array}$ \\
\hline
\end{tabular}


Table 2. Cont.

\begin{tabular}{|c|c|c|c|c|}
\hline \multicolumn{5}{|c|}{ Anticancer Activity } \\
\hline S. No. & Microalgae species & Compound/Fraction & Application & References \\
\hline 1. & Nostoc muscorum & $\begin{array}{c}\text { Phycobilins, phenolic } \\
\text { compounds and polysaccharides }\end{array}$ & $\begin{array}{l}\text { Anticancer activity against cell lines } \\
\text { of Ehrlich Ascites Carcinoma and } \\
\text { Human hepatocellular cancer }\end{array}$ & $\begin{array}{l}\text { Shanab et al., } 2012 \text { [90]; } \\
\text { Sheih et al., } 2010 \text { [136] }\end{array}$ \\
\hline 2. & Red algae & c-phycocyanin & Anti-proliferation & Kim et al., 2011 [83] \\
\hline 3. & G. impudicum & $\begin{array}{l}\text { sulphate polysaccharide } \\
\text { (p-KG03) }\end{array}$ & Prevents tumor cell growth & Wang et al., 2007 [132] \\
\hline 4. & Chlorella vulgaris & $\beta$-(1,3)-glucan & Antitumor agent & $\begin{array}{c}\text { Delasoie et al., } 2018 \text { [86]; } \\
\text { Laroche and Michaud } 2007 \text { [133] }\end{array}$ \\
\hline 5. & Porphyridium sp. & Sulphated polysaccharides & $\begin{array}{l}\text { Tumor cell inhibition and } \\
\text { proliferation of colon cancer in rats }\end{array}$ & $\begin{array}{l}\text { Geresh et al. } 2002 \text { [135]; } \\
\text { Sun et al. } 2012 \text { [134] }\end{array}$ \\
\hline
\end{tabular}

\section{Functional Food/Feed}

\subsection{Functional Food}

Microalgae are considered as "GRAS" (Generally Regarded as Safe) [165] and marketed as functional foods that benefit health beyond the basic role of nutrition. Nostoc sp. was used in China for food (over 2000 years ago), and later Chlorella sp. and Spirulina sp. were consumed as healthy foods in Japan, Taiwan, and Mexico (39). Microalgae are commercially produced in the Asia-Pacific region with capacities ranging from 3 to 500 tons/year, and the market value for human consumption is $100 € / \mathrm{kg}$ [166]. Currently, microalgae are available in markets as health foods, and their products are mixed with pastes, snacks, candy, gums, noodles, wine, beverages, and breakfast cereals. Auxenochlorella protothecoides, Chlorella vulgaris, Chlorella pyrenoidesa, Dunaliella salina, Dunaliella tertiolecta, and Spirulina platensis are some of the microalgae species widely used in human foods because of their high protein and nutritive value [167]. Besides, Scenedesmus sp. is also used as a nutritional food source in desserts, fruit puddings, ravioli, noodles, and soups, but their commercial production is limited [168]. In fact, the omega-3 acids in fish come from the microalgae consumed at the bottom of the food pyramid and are gradually passed up to the fish at the top [39]. Schizochytrium sp is cultivated by OmegaTech (USA) as an alternative to fish oil to produce DHA-rich oils, namely 'DHA Gold' [75]. In infant-grade milk in Europe, purified PUFAs are added, and chickens are supplemented with microalgae to produce omega-eggs [75]. In USA, EPA + DHA-rich algal oil capsules $\left(\right.$ Pure One $\left.{ }^{\mathrm{TM}}\right)$ are marketed as food supplements [169].

\subsection{Feed-Animal and Aquaculture}

Microalgae are a treasure trove when it comes to nourishment, since they act efficiently as animal and aquaculture hatchery dietary supplements. The global microalgae production for aqua farming reached 1 kiloton (molluscs $-62 \%$; crustaceans $-21 \%$; fishes $-16 \%$ ) and 4.5 kilotons for ruminants and plants [170]. Moreover, microalgae is cost-effective and eco-friendly when compared to other feeds [171]. The protein content $(510-710 \mathrm{~g} / \mathrm{kg})$ and essential amino acids in some microalgal species is greater than normal eggs $(132 \mathrm{~g} / \mathrm{kg})$ and Glycine $\max (370 \mathrm{~g} / \mathrm{kg})$. Spirulina platensis exhibit a protein digestibility rate of $87-97 \%$ [172]. Microalgae-based eggs are marketed as vegan eggs by a UK company with similar nutrition to that of an egg (www.mygenefood.com, accessed on 15 March 2021). As microalgae feed is thick and recalcitrant owing to cell wall with cellulose and polysaccharides, CAZymes are used as a flavor enhancer, which helps in food assimilation [173]. Microalgae species such as Nannochloropsis, Chlorella, Dunaliella, Haematococcus, and Schizochytrium with sizes of $25 \mu \mathrm{M}$ or less are used as feed for zooplankton [174,175]. Shrimps feed entirely on microalgae and zooplankton during their metamorphosis. An algal diet rich in DHA and arachidonic acid (ARA) improved hemocyte count, larvae growth, and antioxidant and bactericidal properties. It also protects against white spot syndrome virus [176]. Fish like sea bream, turbot, seabass, striped mullet, flounders, halibut, Atlantic cod, lobster, and 
Senegalese solely depend on microalgae as live prey/feed in hatcheries [177]. Haematococcus pluvialis, a rich source of astaxanthin, provides pinkening, a nutrient profile, as well as increasing the selling price of the fishes. Utilizing H. pluvialis as feed for farmed salmonid has been recently recommended by the Food and Drug Administration [1]. Carassius auratus (ornamental goldfish), when fed with microalgae, showed enhanced pigmentation. Nannochloropsis sp. is used in finfish hatcheries while Pavlova sp. is used for oyster, broodstock, clams, and mussels to enhance DPA/EPA levels [178]. Chlamydomonas reinhardtii, genetically engineered microalgae, produce bovine lactoferricin, increased PUFA levels, fatty acids, and anti-p57 antibodies [179]. Around 30\% of total algal biomass is marketed as feed or utilized in food formulations [85].

Chlorella sp., Spirulina sp., Arthrospira sp., Porphyridium sp., and Isochrysis sp., are important microalgae species used in animal husbandry [173]. Canthaxanthin containing microalgae is associated with an improved content of vitamin $\mathrm{E}$ in the liver and is also used as a poultry dietary supplement with antioxidant, anti-inflammatory, and neuroprotective properties [41]. Holstein cows fed with microalgae produced enhanced milk yield $\left(34 \mathrm{~kg}\right.$ day $\left.^{-1}\right)$, plasma metabolites, DAH, and linolenic acid [180]. Chlorella pyrenoidosa and Spirulina platensis contained essential nutrients like lactobiose, protein, and saturated fatty acids in the paunch of ruminants [181]. Sheep and Damascus goats, when fed with microalgae, showed high strength, increased protein, and lactobiose content with the same $\mathrm{pH}$ of the alimentary canal. Pregnant ewes supplemented with Spirulina gave birth to ewes 4 times larger than that of normal ones [182,183]. Poultry birds (chickens, ducks, turkeys, and quail) supplemented with microalgae reported being productive concerning body weight, yield, and reduced cholesterol [184]. Feeding chickens with $H$. pluvilais, $N$. gaditana, and Spirulina resulted in higher muscle pigmentation, antioxidant properties in the liver, and carotenoid pigmentation in egg yolk $[185,186]$. The average daily benefit and DHA levels in loin and subcutaneous meat are higher in pigs. Defatted algal biomass of Nannochloropsis sp., on feeding to anemic pigs, elevated blood hemoglobin, hematocrit, and growth [187]. Drosophila melanogaster, when fed with Chlorella vulgaris and Senedesmus obliqus, showed increased total weight, longer travel distance, and higher serotonin levels [188].

\section{Microalgae Cultivation}

Microalgae are versatile microorganisms that can grow under phototrophic, heterotrophic, and mixotrophic growth conditions and possess the ability to adapt to different environmental conditions by altering cellular mechanisms [189]. Microalgae are grown in a wide variety of indoor and outdoor cultivation systems, such as vertical column photobioreactors, raceway pools, tubular closed photobioreactors, lagoons, bubble columns, pilot tanks, earthen pots, basins, and concrete tanks (Figure 1) $[13,20,190]$. The cultivation system should have a short path length, adequate microalgae culture for proper mixing, and full light dispersion [191]. Microalgae growth and product formation do not occur simultaneously. To overcome this challenge, microalgae are grown under a two-stage cultivation system, where microalgae are grown initially under nutrient-rich conditions to achieve maximum biomass productivity, followed by nutrient-deprived conditions for cellular morphogenesis and stimulation of value-added products [192,193]. Proteins, carbohydrates, and lipids are synthesized during the growth phase, while amelioration of these products occurs under nutrient-deprived and stress conditions [8]. Light [194], temperature [195], $\mathrm{pH}$ [196], salinity [197], trace metals [198], Ultraviolet Radiation [199], and dark-light photoperiods are the important key factors essential for enhanced biomass production and targeted biomolecules [52]. Chlorella vulgaris grown under nitrogen-rich conditions achieved a maximum lipid productivity of $71.1 \mathrm{mg} \mathrm{L}^{-1} \mathrm{~d}^{-1}$ [200]. Chlorococcum, a cosmopolitan microalga tolerant to extreme $\mathrm{pH}$ and temperature, produces astaxanthin, canthaxanthin, lutein, $\beta$-carotene, adonixanthin, and cis-isomers of ketocarotenoid [201]. H. Plulvalis accumulates $95 \%$ of total carotenoids and increased fatty acid biosynthesis due to improvements in environmental conditions (light strength, temperature, salinity, and 
nutrient limitation) [202]. Although reduced amounts of nutrient have shown propitious results, utilizing wastewater as a nutrient source has been considered promising and an alternative to economic cultivation $[203,204]$. Nitrates and phosphates can serve as essential nutrients while acetate can be utilized as organic carbon for algal cultivation [205,206]. Apart from external stress conditions, researchers have now targeted genetic engineering and manipulation of metabolic pathways that redirect cellular functions in the synthesis of compounds of interest, enlarging the competences of microalgae. Homologous recombination, RNA silencing, selection marker, biolistic transformation, artificial hybrids, somatic variants, and mutant's development are communal tools used in genetic engineering for pharmaceutical and nutraceutical products of monetary value $[5,20]$. To date, over 40 different microalgae species have been successful in genetic manipulation including the green algae Chlorellavulgaris, Haematococcus pluvialis, Dunaliellasalina, Chlamydomonas reinhardtii, and the Bacillariophyceae Phaeodactlyum tricornutum and Thalassiosira pseudonana [207]. Today, microalgae represent a viable source for recovery of high value-added products and have drawn attention for their use in health products in addition to biofuels.
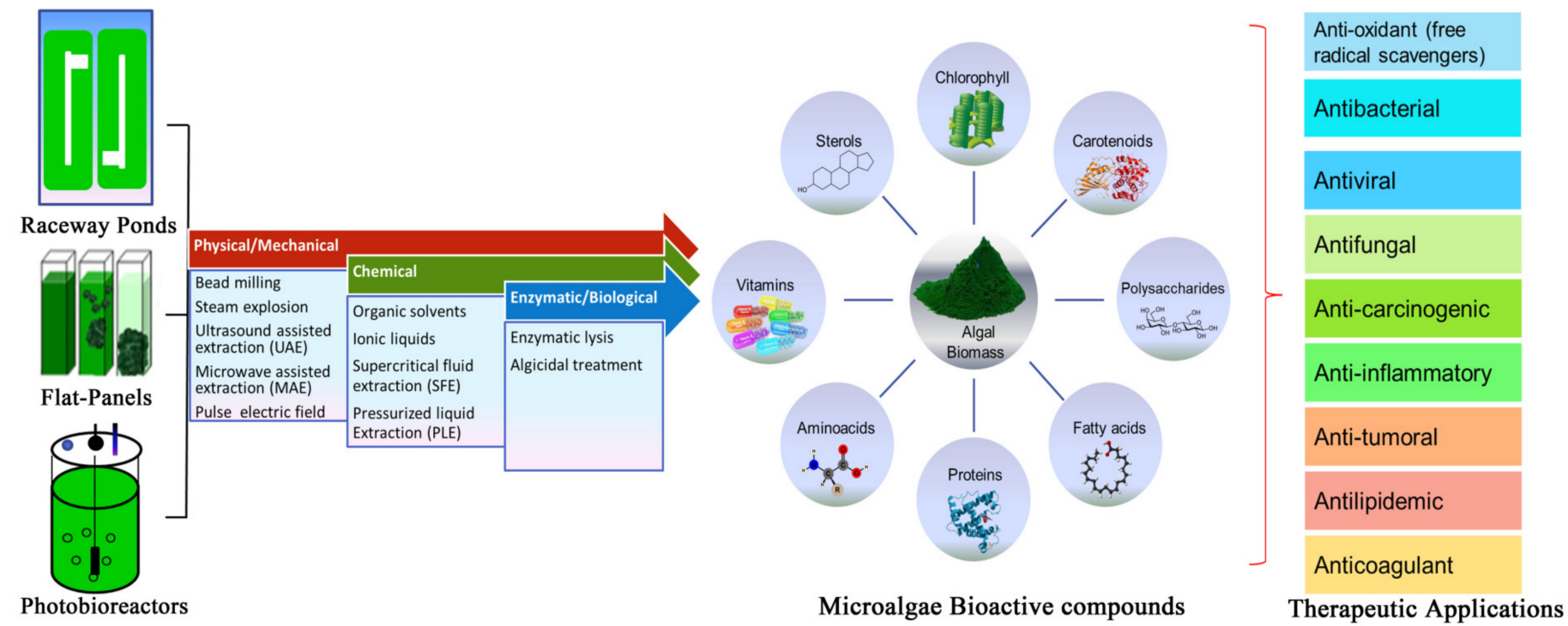

Figure 1. Stepwise illustration of algal biorefinery and their therapeutic activity.

\section{Harvesting and Downstream Process of Microalgae}

The downstream method entails lower-cost exploitation of high-value microalgae metabolites with high product recovery. The composition and productivity of microalgae mainly depends on cultivation mode, nutrient composition, and harvesting time [208]. The most commonly used harvesting techniques for performance, operating economy, and technological feasibility are membrane filtration, centrifugation, microfiltration, ultrafiltration, gravity sedimentation, electrolytic phase, electrophoresis, and magnetic separation [209]. Harvesting of microalgae is challenging as these are microscopic $(3-30 \mu \mathrm{m})$, with low sedimentation rates and negative surface charges, which cause repulsion between the cells. Gravitational sedimentation and filtration are widely employed to harvest relatively large $(>70 \mu \mathrm{m})$ microalgae Spirulina and Coelastrum [210]. However, microalgae with dimensions $(<30 \mu \mathrm{m})$, such as Scenedesmus, Dunaliella, and Chlorella, often blind the filter, and frequent replacement results in high operational costs [211]. The preferable harvesting method is chosen according to the attributes of the microalgae (size, species, and cell density) and the final product. Conjoining chemical or biological coagulation/flocculation harvesting methods will improve process productivity and minimize operational costs [212]. The microalgae cell wall is a complex and tri-layered structure typically composed of polysaccharides (cellulose, pectin, and xylan), proteins (glycoproteins), and sugars, making them highly recalcitrant to degradation [213]. The cell wall has high mechanical strength 
and chemical resistance due to the presence of covalent, hydrogen, and van der Waals forces [214]. The exposure of microalgae cells to harsh shear levels, high temperatures, and pressure may change the integrity, loss of functionality, and subsequent release of the compound. For example, microalgal cell wall tensile strength is up to $9.5 \mathrm{MPa}$, which is three times that of Daucus carota [215]. It is important to use mild pre-treatment procedures to promote the recovery of the delicate intracellular compounds from the microscopic cell. Microalgae cells can be pre-treated/disrupted individually or in amalgamations, i.e., (1) mechanical/physical, (2) chemical, and (3) enzymatic/biological pre-treatment method (Figure 1).

\subsection{Mechanical/Physical Pre-Treatment}

Mechanical/physical cell disruption involves the breakdown of the cell wall to expedite the entry of solvents and solubilize intracellular complexes. Pre-treatment of microalgae cells can be carried out using bead milling, steam explosion, ultrasonication, and microwave-assisted extraction. Steam explosion is a cost-effective and efficient cell disruption method. Lorente et al., reported that N. gaditana, C. sorokiniana, and P. tricornutum achieved the highest lipid extraction yields using steam explosion [216]. Glass beads, zirconia-silica, zirconium oxide, or titanium carbide with $0.5 \mathrm{~mm}$ diameter is effective in microalgae disruption for the release of intracellular compounds. Bead milling of C. vulgaris releases water-soluble proteins with yields ranging between $32 \%$ to $42 \%$ and energy consumption below $2.5 \mathrm{kWhkg}^{-1}$ dry weight [217]. Bead milling perturbation of $\mathrm{H}$. pluvialis improves the recovery of astaxanthin by up to $98 \%$ during extraction at $400 \mathrm{rpm}$ for $5 \mathrm{~min}$ [218]. Ultrasound-assisted extraction (UAE) is an efficient, economical, and rapid extraction method for the disruption of cell walls [219]. It works with low amounts of solvents and low temperatures to preserve thermolabile compounds and structural properties of the by-product. Polyphenols, antioxidants, and phycobiliproteins are the main compounds extracted from microalgae using UAE. In the destruction of cell membranes and the extraction of separate intracellular compounds, the energy strength of $0.4 \mathrm{kWh} \mathrm{L}^{-1}$ gained worldwide interest [220]. The UAE process obtained a yield of $15.6 \%$ phycocyanin in $20 \mathrm{~min}$ in Spirulina platensis, while the extraction of Soxhlet took $4 \mathrm{~h}$ to extract $11.1 \%$ [221]. Microwave-assisted extraction (MAE) yields high-value biological compounds by dissipating electromagnetic waves in the irradiated medium [222]. MAE has been used for the pretreatment of a variety of microalgae classes including Chlorophyceae, Bacillariophyceae, Eustigmatophyceae, and Phaeophyceae [223]. MAE is widely employed to extract bioactive compounds such as alkaline galactans, carrageenans, polysaccharide, and agar from Chlorella, Haematococcus, Bacillariophyceae, and seaweeds with high mechanical resistance and silica frustules [224,225].

\subsection{Chemical Pre-Treatment}

Chemical pre-treatments are easy with less energy inputs and high scalability but the major drawback is chemical toxicity and product recovery. Chemical solvents, salts, bases, ozone, and ionic liquids are widely used to extract bioactive compounds from algal biomass [226]. For their use in pharmaceuticals/nutraceuticals, the US Food and Drug Administration (FDA) categorized solvents into different groups and proposed allowed daily exposure (PDE) limits for each solvent. Chloroform PDE, for example, is equivalent to $0.6 \mathrm{mgday}^{-1}$, whereas hexane can be used up to 2.9 mgday $^{-1}$ [227]. Chemical treatment of Thraustochytrids biomass for astaxanthin extraction showed higher yields with inorganic acids compared to organic ones [228]. Ionic liquids are liquid-state molten organic salts composed of an asymmetric cation and inorganic anion. Owing to their synthetic stability, solubility, conductivity, polarity, and hydrophobicity in the range of cationic or anionic constituents, these are known as designer solvents [22]. Ionic liquids break down complex networks of lignin, cellulose, and hemicellulose due to their high capacity to accept hydrogen bonds [229]. Imidazolium- and cholinium-based ILs are widely investigated 
for their potential to extract bioactive compounds from Synechocystis sp., Scenedesmus sp., C. vulgaris, and Spirulina [230].

Supercritical fluid extraction (SFE) is a promising technology for green extraction, focused on the use of solvents above their critical temperatures and pressures. SFE is popularly used for the recovery of lipids from microalgae [226]. Different solvents such as ethanol, methanol, hexane, butane, and sulfur hexafluoride are used for the abstraction of biological composites using $\mathrm{CO}_{2}$ as a supercritical fluid. SCF-CO $\mathrm{CO}_{2}$ easily infiltrates the microalgae cell wall due to its high permeability and diffusivity that solubilizes intracellular compounds [231]. Sanzo et al., stated that astaxanthin and lutein yield was enhanced to $98.6 \%$ and $52 \%$ by varying the pressure from 10 to $50 \mathrm{MPa}$ at $50{ }^{\circ} \mathrm{C}$ and $\mathrm{CO}_{2}$ flow rate of $14.48 \mathrm{gmin}^{-1}$ in H. pluvialis [35]. Increased extraction time, temperature, and pressure increased the recovery of $79.6 \%$ DHA from Nannochloropsis sp. [232]. A similar phenomenon was observed by Molino et al., with the isolation of carotenoids from D. salina [233]. Pressurized Fluid Extraction (PFE) is a technique that uses high temperature (below critical point) and pressure during the extraction process to retain the solvent in a liquid state [234]. Water is used as extraction solvent and an alternative to organic solvents in Pressurized Liquid Extraction (PLE) because it has the same similar dielectric constant (ethanol or methanol) and solvent characteristics to that of organic solvents. Carotenoids are widely extracted compounds through PLE method. Ethanol/acetone/water has shown promising results as solvents in the PLE method for the extraction of different kinds of carotenoids from Phormidium sp., Phaeodactylum tricornutum, Chlorococcum sp., Neochloris oleoabundans, Scenedesmus sp., and C. vulgaris $[235,236]$.

\subsection{Enzymatic/Biological Pre-Treatment}

Enzymatic disruption is a non-destructive pre-treatment method to facilitate the access of microalgae cellular components. It is a cost-intensive process, is highly effective, and operates under mild environmental conditions with less energy demand [237]. During lysis, enzymes act selectively, lyse, and degrade specific chemical linkage without destroying particle existence or any non-specific reaction in the solution. For cell lysis, lytic enzymes such as glycosidases, glucanases, cellulose, pectinase, and lipases have been used extensively [214]. Tang et al., reported that the utilization of carbohydrases disrupts the cell wall and enhances protein yield from rice bran [238]. Papain hydrolyzed from $N$. incerta demonstrated higher antioxidant activity relative to alcalase, neutrase, alpha-chymotrypsin, pepsin, pronase-E, and trypsin [239]. Recent studies demonstrated that the simultaneous use of enzymes facilitates the extraction of intracellular compounds. For example, cellulase hydrolyzes the cellulosic structure while lysozyme degrades resilient polymers present on the microalgae envelope [240]. The combination of chemical or mechanical treatment with enzymatic cell disruption may minimize the expense of the enzymatic procedure, the use of solvents, energy consumption, and improve the efficiency of intracellular material recovery. Emerging cell destruction developments that are still under development are explosive decompression, microfluidization, pulsed arc technology, and disruption using cationic polymer-coated membranes.

\section{Conclusions and Future Perspective}

Bioactive metabolites of microalgal origin have gained the biotechnological spotlight to decelerate the rate of malnourishment in developing nations. Even today, 1 out of 10 is undernourished due to malnutrition. Bioactive compounds obtained from microalgae, such as polyunsaturated fatty acids, carotenoids, phycobiliproteins, polysaccharides, antioxidants, sterols, and other secondary metabolites, have significant potential through a sustainable approach to meet increasing global demands. Microalgae metabolites act as the repository of natural antibiotics benefitting animal/aquaculture and human health by replacing antimicrobial compounds of synthetic origin. Microalgae are more nutritious, productive, and could be the next alternative for traditional sources of animal and aquatic feed with enriched eggs, meat, and milk. Microalgae-derived bioactive metabolites are 
renowned for antioxidant and broad-spectrum anti-inflammatory and antibacterial properties with impressive safety profiles, which help in the reduction and prevention of diseases associated with oxidative stress. The application of bioactive compounds proved to be beneficial and much more effective when compared to present traditional treatments and therapies. These metabolites act widely against emerging infectious diseases, antibiotic resistant bacteria, viral infections (epidemic and pandemic), and can prevent the delay or onset of chronic and carcinogenic diseases. Although numbers of products isolated from microalgae are commercially available for human health and nutrition, the social acceptance and awareness of health benefits of microalgae are still lacking. When eaten entirely, the chemical constituents of microalgae can exert synergistic results. In order to exploit the pharmacological and biological properties of algal-derived materials, numerous in vivo clinical studies are also required. Microalgae cultivation in different wastewater streams using genetically modified techniques explores their biotechnological potential to favor bio-based process. Sequential or co-extraction of multiple bioactive compounds with low energy consumption and high yields needs to be prioritized. Nonetheless, more studies are needed to turn the current technology into green technology for the exploitation of microalgae in bioengineering and fulfill the requirements compared to plants.

Author Contributions: Conceptualization, S.V.M. and B.R.K.; writing-original draft preparation, B.R.K.; supervision, S.V.M.; funding acquisition, S.V.M. All authors have read and agreed to the published version of the manuscript.

Funding: The authors acknowledge financial assistance in the form of a project (BT/HRD/35/01/02/2018) from the Department of Biotechnology (DBT), Government of India.

Institutional Review Board Statement: Not applicable.

Informed Consent Statement: Not applicable.

Acknowledgments: The authors would like to thank CSIR-IICT for its support (Manuscript No. IICT/Pubs./2020/186).

Conflicts of Interest: The authors declare no conflict of interest.

\section{References}

1. United Nations Department of Economic and Social Affairs (UNDES). World Population Projected to Reach 9.8 Billion in 2050, and 11.2 Billion in 2100. 2017. Available online: https://www.un.org/development/desa/en/news/population/world-populationprospects-2017.html (accessed on 19 March 2018).

2. Sreeharsha, R.V.; Venkata Mohan, S.V. Symbiotic integration of bioprocesses to design a self-sustainable life supporting ecosystem in a circular economy framework. Bioresour. Technol 2021, 124712. [CrossRef]

3. FAO. World Agriculture: Towards 2015/2030, Summary Report (2002). Available online: http://www.fao.org/docrep/004/Y355 7E/y3557e03.htm (accessed on 19 March 2018).

4. FAO. Protein Sources for the Animal Feed Industry. 2004. Available online: http://www.fao.org/docrep/007/y5019e/y5019e03. htm (accessed on 23 March 2018).

5. Sudhakar, M.P.; Kumar, B.R.; Mathimani, T.; Arunkumar, K. A review on bioenergy and bioactive compounds from microalgae and macroalgae-sustainable energy perspective. J. Clean. Prod. 2019, 228, 1320-1333. [CrossRef]

6. Sosa-Hernández, J.E.; Escobedo-Avellaneda, Z.; Iqbal, H.; Welti-Chanes, J. State-of-the-art extraction methodologies for bioactive compounds from algal biome to meet bio-economy challenges and opportunities. Molecules 2018, 23, 2953. [CrossRef]

7. Torres-Tiji, Y.; Fields, F.J.; Mayfield, S.P. Microalgae as a future food source. Biotechnol. Adv. 2020, 107536. [CrossRef] [PubMed]

8. Venkata Mohan, S.; Hemalatha, M.; Chakraborty, D.; Chatterjee, S.; Ranadheer, P.; Kona, R. Algal biorefinery models with self-sustainable closed loop approach. Trends and prospective for blue-bioeconomy. Bioresour. Technol. 2020, 122128. [CrossRef] [PubMed]

9. Venkata Mohan, S.; Rohit, M.V.; Chiranjeevi, P.; Hariprasad, R.; Arora, S. Integrating microalgae cultivation with wastewater treatment for biodiesel production. In Algal Biorefinery: An Integrated Approach; Springer: Cham, Switzerland, 2015; pp. 321-337.

10. dos Santos Alves Figueiredo Brasil, B.; Gonçalves de Siqueira, F.; Chan Salum, T.F.; Zanette, C.M.; Spier, M.R. Microalgae and cyanobacteria as enzyme biofactories. Algal Res. 2017, 25, 76-89.

11. Levasseur, W.; Perré, P.; Pozzobon, V. A review of high value-added molecules production by microalgae in light of the classification. Biotechnol. Adv. 2020, 107545. [CrossRef]

12. Barkia, I.; Saari, N.; Manning, S.R. Microalgae for high-value products towards human health and nutrition. Mar. Drugs. 2019, 17, 304. [CrossRef] 
13. Yin, Z.; Zhu, L.; Li, S.; Hu, T.; Chu, R.; Mo, F.; Hu, D.; Liu, C.; Li, B. A comprehensive review on cultivation and harvesting of microalgae for biodiesel production: Environmental pollution control and future directions. Bioresour. Technol. 2020, 301, 122804. [CrossRef]

14. Koyande, A.K.; Chew, K.W.; Rambabu, K.; Tao, Y.; Chu, D.T.; Show, P.L. Microalgae: A potential alternative to health supplementation for humans. Food Sci. Hum. Wellness 2019, 8, 16-24. [CrossRef]

15. Globe Newswire. Herbal Nutraceutical Supplements in Vogue as Consumer Preference for Natural Soars. Available online: http:/ / in.style.yahoo.com/herbal-nutraceutical-supplements-vogue-consumer-143000805.html (accessed on 18 December 2018).

16. Williams, R. Microscopic Algae Produce Half the Oxygen we Breathe. ABC News. October 2013. Available online: http://www. abc.Net.au/radionational/programs/scienceshow/microscopic-algae-produce-half-the-oxygen-we-breathe/5041338. (accessed on 19 May 2019).

17. Da Silva Vaz, B.; Moreira, J.B.; de Morais, M.G.; Costa, J.A.V. Microalgae as a new source of bioactive compounds in food supplements. Curr. Opin. Food Sci. 2016, 7, 73-77.

18. Kılınç, B.; Cirik, S.; Turan, G.; Tekogul, H.; Koru, E. Seaweeds for food and industrial applications. InTechOpen 2013, 735-747. [CrossRef]

19. Jacob-Lopes, E.; Maroneze, M.M.; Deprá, M.C.; Sartori, R.B.; Dias, R.R.; Zepka, L.Q. Bioactive food compounds from microalgae: An innovative framework on industrial biorefineries. Curr. Opin. Food Sci. 2019, 25, 1-7. [CrossRef]

20. Wilson, G.M., Jr.; Gorgich, M.; Corrêa, P.S.; Martins, A.A.; Mata, T.M.; Caetano, N.S. Microalgae for biotechnological applications. Cultivation, harvesting and biomass processing. Aquaculture 2020, 735562. [CrossRef]

21. Vuppaladadiyam, A.K.; Prinsen, P.; Raheem, A.; Luque, R.; Zhao, M. Microalgae cultivation and metabolites production: A comprehensive review. Biofuel Bioprod. Biorefin. 2018, 12, 304-324. [CrossRef]

22. Tang, D.Y.Y.; Khoo, K.S.; Chew, K.W.; Tao, Y.; Ho, S.H.; Show, P.L. Potential utilization of bioproducts from microalgae for the quality enhancement of natural products. Bioresour. Technol. 2020, 122997. [CrossRef]

23. Onofrejova, L.; Vasickova, J.; Klejdus, B.; Stratil, P.; Misurcova, L.; Kracmar, S.; Kopecky, J.; Vacek., J. Bioactive phenols in algae: The application of pressurized-liquid and solid-phase extraction techniques. J. Pharm. Biomed. Anal. 2010, 51, e464-e470. [CrossRef] [PubMed]

24. Balasubramaniam, V.; Gunasegavan, R.D.; Mustar, S.; Lee, J.C.; Mohd Noh, M.F. Isolation of industrial important bioactive compounds from microalgae. Molecules 2021, 26, 943. [CrossRef]

25. Rosas, J.G.; Gómez, N.; Cara-Jiménez, J.; González-Arias, J.; Olego, M.Á.; Sánchez, M.E. Evaluation of Joint Management of Pine Wood Waste and Residual Microalgae for Agricultural Application. Sustainability 2021, 13, 53. [CrossRef]

26. Odjadjare, E.C.; Mutanda, T.; Olaniran, A.O. Potential biotechnological application of microalgae: A critical review. Crit. Rev. Biotechnol. 2017, 37, 37-52. [CrossRef]

27. Mishra, V.K.; Bacheti, R.K.; Husen, A. Medicinal uses of chlorophyll: A critical overview. In Chlorophyll: Structure, Function and Medicinal; Le, H., Salcedo, E., Eds.; Nova Science Publishers: Hauppauge, NY, USA, 2011; pp. 177-196.

28. Khanra, S.; Mondal, M.; Halderl, G.; Tiwari, O.N.; Gayen, K.; Bhowmick, T.K. Downstream processing of microalgae for pigments, protein and carbohydrate in industrial application: A review. Food Bioprod. Process 2018, 110, 60-84. [CrossRef]

29. Rajesh, K.; Rohit, G.; Venkata Mohan, S. Microalgae-based carotenoids production. In Algal Green Chemistry; Rastogi, R.P., Madamwar, D., Pandey, A., Eds.; Elsevier: Amsterdam, The Netherlands, 2017; pp. 139-147.

30. Galasso, C.; Gentile, A.; Orefice, I.; Ianora, A.; Bruno, A.; Noonan, D.M.; Sansone, C.; Albini, A.; Brunet, C. Microalgal derivatives as potential nutraceutical and food supplements for human health: A focus on cancer prevention and interception. Nutrients 2019, 11, 1226. [CrossRef]

31. Gong, M.; Bassi, A. Carotenoids from microalgae: A review of recent developments. Biotechnol. Adv. 2016, 34, 1396-1412. [CrossRef]

32. Capelli, R.; Talbott, S.; Ding, L. Astaxanthin sources: Suitability for human health and nutrition. Funct. Foods Health Dis. 2019, 9 , 430-445. [CrossRef]

33. Talukdar, J.; Dasgupta, S.; Nagle, V.; Bhadra, B. COVID-19: Potential of Microalgae Derived Natural Astaxanthin as Adjunctive Supplement in Alleviating Cytokine Storm. 2020. Available online: https://dx.doi.org/10.2139/ssrn.3579738 (accessed on 18 April 2020).

34. Lin, J.H.; Lee, D.J.; Chang, J.S. Lutein production from biomass: Marigold flowers versus microalgae. Bioresour. Technol. 2015, 184, 421-428. [CrossRef]

35. Sanzo, G.D.; Mehariya, S.; Martino, M.; Larocca, V.; Casella, P.; Chianese, S.; Musmarra, D.; Balducchi, R.; Molino, A. Supercritical carbon dioxide extraction of astaxanthin, lutein, and fatty acids from Haematococcus pluvialis microalgae. Mar. Drugs 2018, 16, 334. [CrossRef]

36. Abu-Ghosh, S.; Dubinsky, Z.; Verdelho, V.; Iluz, D. Unconventional high-value products from microalgae. A review. Bioresour. Technol. 2021, 124895. [CrossRef]

37. Folarin, O.; Sharma, L. Algae as a functional food. Int. J. Home Sci. 2017, 3, 166-170.

38. Katiyar, R.; Arora, A. Health promoting functional lipids from microalgae pool: A review. Algal Res. 2020, 46, e101800. [CrossRef]

39. Sathasivam, R.; Radhakrishnan, R.; Hashem, A.; Abd-Allah, E.F. Microalgae metabolites: A rich source for food and medicine. Saudi J. Biol. Sci. 2019, 26, 709-722. [CrossRef]

40. Rohit, M.V.; Venkata Mohan, S. Quantum Yield and Fatty Acid Profile Variations with Nutritional Mode during Microalgae Cultivation. Front. Bioeng. Biotechnol. 2018, 6, 111. [CrossRef] 
41. Charles, C.N.; Msagati, T.; Swai, H.; Chacha, M. Microalgae: An alternative natural source of bioavailable omega-3 DHA for promotion of mental health in East Africa. Sci. African. 2019, 6, e00187. [CrossRef]

42. Bhalamurugan, G.L.; Valerie, O.; Mark, L.; Chacha, M. Valuable bioproducts obtained from microalgal biomass and their commercial applications: A review. Environ. Eng. Res. 2018, 23, 229-241. [CrossRef]

43. Chiranjeevi, P.; Venkata Mohan, S. Critical parametric influence on microalgae cultivation towards maximizing biomass growth with simultaneous lipid productivity. Renew. Energy 2016, 98, 64-71. [CrossRef]

44. Cesário, M.T.; da Fonseca, M.M.R.; Marques, M.M.; de Almeida, M.C.M. Marine algal carbohydrates as carbon sources for the production of biochemicals and biomaterials. Biotechnol. Adv. 2018, 36, 798-817. [CrossRef] [PubMed]

45. Chen, L.; Huang, G. The antiviral activity of polysaccharides and their derivatives. Int. J. Biol. Macromol. 2018, 115, 77-82. [CrossRef] [PubMed]

46. De Morais, M.G.; Vaz, B.D.S.; de Morais, E.G.; Costa, J.A.V. Biologically active metabolites synthesized by microalgae. BioMed Res. Int. 2015, 835761. [CrossRef]

47. Gardeva, E.; Toshkova, R.; Minkova, K.; Gigova, L. Cancer protective action of polysaccharide, derived from red microalga Porphyridium cruentum-A biological background. Biotechnol. Biotechnol. Equip. 2009, 23, 783-787. [CrossRef]

48. Lekshmi, V.S.; Kurup, G.M. Anticoagulant activities of sulfated polysaccharides from the edible marine algae Padina tetrastromatica and Ulva fasciata: A combined in vitro and in vivo approach. J. Pharmacogn. Phytochem. 2019, 8, 693-698.

49. Gaikwad, M.; Pawar, Y.; Nagle, V.; Dasgupta, S. Marine red alga Porphyridium sp. as a source of sulfated polysaccharides (SPs) for combating against COVID-19. Preprints 2020, 2020040168, in press.

50. Caporgno, M.P.; Mathys, A. Trends in microalgae incorporation into innovative food products with potential health benefits. Front. Nutr. 2018, 5, 58. [CrossRef]

51. Hempel, F.; Lau, J.; Klingl, A.; Maier, U.G. Algae as protein factories: Expression of a human antibody and the respective antigen in the diatom Phaeodactylum tricornutum. PLoS ONE 2011, 6, e28424.

52. Paliwal, C.; Mitra, M.; Bhayani, K.; Bharadwaj, S.V.; Ghosh, T.; Dubey, S.; Mishra, S. Abiotic stresses as tools for metabolites in microalgae. Bioresour. Technol. 2017, 244, 1216-1226. [CrossRef]

53. Hempel, F.; Maier, U.G. Microalgae as solar-powered protein factories. In Advanced Technologies for Protein Complex Production and Characterization; Springer: Cham, Switzerland, 2016; pp. 241-262.

54. Gregory, J.A.; Topol, A.B.; Doerner, D.Z.; Mayfield, S. Alga-produced cholera toxin-Pfs25 fusion proteins as oral vaccines. Appl. Environ. Microbiol. 2013, 79, 3917-3925. [CrossRef]

55. Specht, E.; Miyake-Stoner, S.; Mayfield, S. Micro-algae come of age as a platform for recombinant protein production Biotechnol. Lett. 2010, 32, 1373-1383. [CrossRef]

56. Andrade, L.M.; Andrade, C.J.; Dias, M.; Nascimento, C.A.O.; Mendes, M.A. Chlorella and Spirulina Microalgae as Sources of Functional Foods, Nutraceuticals, and Food Supplements; an overview. MOJ Food Process Technol. 2018, 6, 45-58.

57. Marzieh Hosseini, S.; Shahbazizadeh, S.; Khosravi-Darani, K.; Reza Mozafari, M. Spirulina paltensis: Food and function. Curr. Nutr. Food Sci. 2013, 9, 189-193.

58. Tarento, T.D.; McClure, D.D.; Vasiljevski, E.; Schindeler, A.; Dehghani, F.; Kavanagh, J.M. Microalgae as a source of vitamin K1. Algal Res. 2018, 36, 77-87.

59. Giammanco, M.; Di Majo, D.; La Guardia, M.; Aiello, S.; Crescimannno, M.; Flandina, C.; Tumminello, F.M.; Leto, G. Vitamin D in cancer chemoprevention. Pharm. Biol. 2015, 53, 1399-1434.

60. Bong, S.C.; Loh, S.P. A study of fatty acid composition and tocopherol content of lipid extracted from marine microalgae, Nannochloropsis oculata and Tetraselmis suecica, using solvent extraction and supercritical fluid extraction. Int. Food Res. J. 2013, $20,721-729$.

61. Lopes, G.; Sousa, C.; Valentao, P.; Andrade, P.B. Sterols in algae and health. In Bioactive Compounds from Marine Foods: Plant and Animal Sources; Hernandez-Ledesma, B., Herrero, M., Eds.; John Wiley \& Sons: Hoboken, New Jersey, USA, 2013 ; pp. 173-191. ISBN 9781118412893.

62. Luo, X.; Su, P.; Zhang, W. Advances in microalgae-derived phytosterols for functional food and pharmaceutical applications. Mar. Drugs 2015, 13, 4231-4254.

63. Ahmed, F.; Zhou, W.; Schenk, P.M. Pavlova lutheri is a high-level producer of phytosterols. Algal Res. 2015, 10, $210-217$.

64. Koller, M.; Muhr, A.; Braunegg, G. Microalgae as versatile cellular factories for valued products. Algal Res. 2014, 6, 52-63. [CrossRef]

65. Cai, X.; Chen, Y.; Xie, X.; Yao, D.; Ding, C.; Chen, M. Astaxanthin prevents against lipopolysaccharide-induced acute lung injury and sepsis via inhibiting activation of MAPK/NF-кB. Am. J. Transl. Res. 2019, 11, 1884.

66. Chang, C.H.; Chen, C.Y.; Chiou, J.Y.; Peng, R.Y.; Peng, C.H. Astaxanthine secured apoptotic death of PC12 cells induced by $\beta$-amyloid peptide 25-35: Its molecular action targets. J. Med. Food 2010, 13, 548-556. [CrossRef] [PubMed]

67. Park, J.S.; Chyun, J.H.; Kim, Y.K.; Line, L.L.; Chew, B.P. Astaxanthin decreased oxidative stress and inflammation and enhanced immune response in humans. Nutr. Metab. 2010, 7, 18. [CrossRef]

68. Wu, Q.; Zhang, X.S.; Wang, H.D.; Zhang, X.; Yu, Q.; Li, W.; Zhou, M.L.; Wang, X.L. Astaxanthin activates nuclear factor erythroidrelated factor 2 and the antioxidant responsive element (Nrf2-ARE) pathway in the brain after subarachnoid hemorrhage in rats and attenuates early brain injury. Mar. Drugs 2014, 12, 6125-6141. [CrossRef] 
69. Liu, T.; Liu, W.H.; Zhao, J.S.; Meng, F.Z.; Wang, H. Lutein protects against $\beta$-amyloid peptide-induced oxidative stress in cerebrovascular endothelial cells through modulation of Nrf-2 and NF-kb. Cell Biol. Toxicol. 2017, 33, 57-67.

70. Rasmussen, H.M.; Johnson, E.J. Nutrients for the aging eye. Clin. Interv. Aging 2013, 8, 741-748.

71. Sansone, C.; Galasso, C.; Orefice, I.; Nuzzo, G.; Luongo, E.; Cutignano, A.; Romano, G.; Brunet, C.; Fontana, A.; Esposito, F.; et al. The green microalga Tetraselmis suecica reduces oxidative stress and induces repairing mechanisms in human cells. Sci. Rep. 2017, 7, 1-12.

72. Morokutti-Kurz, M.; Graf, C.; Prieschl-Grassauer, E. Amylmetacresol/2, 4-dichlorobenzyl alcohol, hexylresorcinol, or carrageenan lozenges as active treatments for sore throat. Int. J. Gen. Med. 2017, 10, 53-60. [CrossRef]

73. Olasehinde, T.A.; Olaniran, A.O.; Okoh, A.I. Therapeutic potentials of microalgae in the treatment of Alzheimer's disease. Molecules 2017, 22, 480. [CrossRef] [PubMed]

74. Raposo, M.F.D.J.; Morais, A.M. Bioactivity and applications of polysaccharides from marine microalgae. Mar. Drugs. 2014, $11,233-252$.

75. Long, S.F.; Kang, S.; Wang, Q.Q.; Xu, Y.T.; Pan, L.; Hu, J.X.; Li, M.; Piao, X.S. Dietary supplementation with DHA-rich microalgae improves performance, serum composition, carcass trait, antioxidant status, and fatty acid profile of broilers. Poult. Sci. 2018, 97, 1881-1890. [CrossRef]

76. Raghukumar, S. Thraustochytrid marine protists: Production of PUFAs and other emerging technologies. Mar. Biotechnol. 2008, 10, 631-640. [CrossRef]

77. Teng, E.; Taylor, K.; Bilousova, T.; Weiland, D.; Pham, T.; Zuo, X.; Yang, F.; Chen, P.P.; Glabe, C.G.; Takacs, A.; et al. Dietary DHA supplementation in an APP/PS1 transgenic rat model of AD reduces behavioral and A $\beta$ pathology and modulates A $\beta$ oligomerization. Neurobiol. Dis. 2015, 82, 552-560. [CrossRef] [PubMed]

78. Mourelle, M.L.; Gómez, C.P.; Legido, J.L. The potential use of marine microalgae and cyanobacteria in cosmetics and thalassotherapy. Cosmetics 2017, 4, 46. [CrossRef]

79. Day, A.G.; Brinkmann, D.; Franklin, S.; Espina, K.; Rudenko, G.; Roberts, A.; Howse, K.S. Safety evaluation of a high-lipid algal biomass from Chlorella protothecoides. Regul. Toxicol. Pharmacol. 2009, 55, 166-180. [CrossRef] [PubMed]

80. Kim, M.; Yim, J.H.; Kim, S.Y.; Kim, H.S.; Lee, W.G.; Kim, S.J.; Kang, P.S.; Lee, C.K. In vitro inhibition of influenza A virus infection by marine microalga-derived sulfated polysaccharide p-KG03. Antivir. Res. 2012, 93, 253-259. [CrossRef]

81. Márquez-Escobar, V.A.; Bañuelos-Hernández, B.; Rosales-Mendoza, S. Expression of a Zika virus antigen in microalgae: Towards mucosal vaccine development. J Biotechnol. 2018, 282, 86-91. [CrossRef] [PubMed]

82. Bhattacharjee, M. Pharmaceutically valuable bioactive compounds of algae. Asian J. Pharm. Clin. Res. 2016, 9, 43-47. [CrossRef]

83. Kim, S.K.; Kang, K.H. Medicinal effects of peptides from marine microalgae. Adv. Food Nutr. Res. 2011, 64, 313-323.

84. Lawrence, K.P.; Long, P.F.; Young, A.R. Mycosporine-like amino acids for skin photoprotection. Curr. Med. Chem. 2018, 25, 5512-5527.

85. Becker, E. Microalgae for Human and Animal Nutrition. In Handbook of Microalgae Culture: Applied Phycology and Biotechnology, 2nd ed.; Richmond, A., Ed.; Blackwell Science: London, UK, 2004; pp. 461-503. ISBN 978-0-4709-9528-0.

86. Desaloie, J.; Rossier, J.; Haeni, L.; Rothen-Rutishauser, B.; Zobi, F. Slow-targeted release of a ruthenium anticancer agent from vitamin B 12 functionalized marine diatom microalgae. Dalton Trans. 2018, 47, 17221-17232. [CrossRef]

87. Kattappagari, K.K.; Teja, C.R.; Kommalapati, R.K.; Poosarla, C.; Gontu, S.R.; Reddyu, B.V.R. Role of antioxidants in facilitating the body functions: A review. J. Orofac. Sci. 2015, 7,71-75. [CrossRef]

88. Goiris, K.; Van Colen, W.; Wilches, I.; León-Tamariz, F.; De Cooman, L.; Muylaert, K. Impact of nutrient stress on antioxidant production in three species of microalgae. Algal Res. 2015, 7, 51-57. [CrossRef]

89. Mostafa, S.S. Microalgal biotechnology: Prospects and applications. Plant Sci. 2012, 12, 276-314.

90. Shanab, S.M.; Mostafa, S.S.; Shalaby, E.A.; Mahmoud, G.I. Aqueous extracts of microalgae exhibit antioxidant and anticancer activities. Asian Pac. J. Trop. Biomed. 2012, 2, 608-615. [CrossRef]

91. Suparmi, S.; Fasitasari, M.; Martosupono, M.; Mangimbulude, J.C. Comparisons of curative effects of chlorophyll from Sauropus androgynus (L.) Merr leaf extract and Cu-chlorophyllin on sodium nitrate-induced oxidative stress in rats. J. Toxicol. $2016,7,8515089$.

92. Matsukawa, R.; Hotta, M.; Masuda, Y.; Chihara, M.; Karube, I. Antioxidants from carbon dioxide fixing Chlorella sorokiniana. J. Appl. Phycol. 2000, 12, 263-267. [CrossRef]

93. Rodrigues, D.B.; Menezes, C.R.; Mercadante, A.Z.; Jacob-Lopes, E.; Zepka, L.Q. Bioactive pigments from microalgae Phormidium autumnale. Food Res. Int. 2015, 77, 273-279. [CrossRef]

94. De Jesus Raposo, M.F.; de Morais, R.M.S.C.; de Morais, A.M.M.B. Health applications of bioactive compounds from marine microalgae. Life Sci. 2013, 93, 479-486. [CrossRef]

95. Shannon, E.; Abu-Ghannam, N. Antibacterial derivatives of marine algae: An overview of pharmacological mechanisms and applications. Mar. Drugs 2016, 14, 81. [CrossRef]

96. Pratt, R.; Daniels, T.C.; Eiler, J.J.; Gunnison, J.B.; Kumler, W.D.; Oneto, J.F.; Strait, L.A.; Spoehr, H.A.; Hardin, G.J.; Milner, H.W.; et al. Chlorellin, an antibacterial substance from Chlorella. Science 1944, 351-352. [CrossRef]

97. Najdenski, H.M.; Gigova, L.G.; Iliev, I.I.; Pilarski, P.S.; Lukavský, J.; Tsvetkova, I.V.; Ninova, M.S.; Kussovski, V.K. Antibacterial and antifungal activities of selected microalgae and cyanobacteria. Int. J. Sci. Food Technol. 2013, 48, 1533-1540.

98. Smith, V.J.; Desbois, A.P.; Dyrynda, E.A. Conventional and unconventional antimicrobials from fish, marine invertebrates and micro-algae. Mar. Drugs 2010, 8, 1213-1262. [CrossRef] 
99. Amaro, H.M.; Guedes, A.C.; Malcata, F.X. Antimicrobial activities of microalgae: An invited review. In Science Against Microbial Pathogens: Communicating Current Research and Technological Advances; Mendez-Vilas, A., Ed.; Formatex Microbiology Book Series: Badajoz, Spain, 2011; pp. 1272-1284. ISBN 978-8-4939-8432-8.

100. Cannell, R.J.; Owsianka, A.M.; Walker, J.M. Results of a large-scale screening programme to detect antibacterial activity from freshwater algae. Br. J. Phycol. 1988, 23, 41-44. [CrossRef]

101. Falaise, C.; François, C.; Travers, M.A.; Morga, B.; Haure, J.; Tremblay, R.; Turcotte, F.; Pasetto, P.; Gastineau, R.; Hardivillier, Y.; et al. Antimicrobial compounds from eukaryotic microalgae against human pathogens and diseases in aquaculture. Mar. Drugs 2016, 14, 159. [CrossRef] [PubMed]

102. Mudimu, O.; Rybalka, N.; Bauersachs, T.; Born, J.; Friedl, T.; Schulz, R. Biotechnological screening of microalgal and cyanobacterial strains for biogas production and antibacterial and antifungal effects. Metabolites 2014, 4, 373-393. [CrossRef] [PubMed]

103. Desbois, A.P.; Mearns-Spragg, A.; Smith, V.J. A fatty acid from the diatom Phaeodactylum tricornutum is antibacterial against diverse bacteria including multi-resistant Staphylococcus aureus (MRSA). Mar. Biotechnol. 2009, 11, 45-52. [CrossRef]

104. Rodríguez-Meizoso, I.; Jaime, L.; Santoyo, S.; Señoráns, F.J.; Cifuentes, A.; Ibáñez, E. Subcritical water extraction and characterization of bioactive compounds from Haematococcus pluvialis microalga. J. Pharm. Biomed. 2010, 51, 456-463.

105. Prakash, J.W.; Marimuthu, J.; Jeeva, S. Antimicrobial activity of certain fresh water microalgae from Thamirabarani River, Tamil Nadu, South India. Asian Pac. J. Trop. Biomed. 2011, 1, S170-S173. [CrossRef]

106. Pane, G.; Cacciola, G.; Giacco, E.; Mariottini, G.L.; Coppo, E. Assessment of the antimicrobial activity of algae extracts on bacteria responsible of external otitis. Mar. Drugs 2015, 13, 6440-6452. [CrossRef] [PubMed]

107. Rendueles, O.; Ghigo, J.M. Multi-species biofilms: How to avoid unfriendly neighbors. FEMS Microbiol. Rev. 2012, 36, 972-989. [CrossRef]

108. Yasuhara-Bell, J.; Lu, Y. Marine compounds and their antiviral activities. Antivir. Res. 2010, 86, 231-240. [CrossRef]

109. Vijayakumar, S.; Menakha, M. Pharmaceutical applications of cyanobacteria-A review. J. Acute Med. 2015, 5, 15-23. [CrossRef]

110. Gerber, P.; Dutcher, J.D.; Adams, E.V.; Sherman, J.H. Protective effect of seaweed extracts for chicken embryos infected with influenza B or mumps virus. Proc. Soc. Exp. Biol. Med. 1958, 99, 590-593. [CrossRef] [PubMed]

111. Hayashi, T.; Hayashi, K.; Maeda, M.; Kojima, I. Calcium spirulan, an inhibitor of enveloped virus replication, from a blue-green alga Spirulina platensis. J. Nat. Prod. 1996, 59, 83-87. [CrossRef] [PubMed]

112. Silva, T.; Salomon, P.S.; Hamerski, L.; Walter, J.; Menezes, R.B.; Siqueira, J.E.; Santos, A.; Santos, J.A.M.; Ferme, N.; Guimarães, T.; et al. Inhibitory effect of microalgae and cyanobacteria extracts on influenza virus replication and neuraminidase activity. Peer 2018, 6, e5716. [CrossRef] [PubMed]

113. Santoyo, S.; Jaime, L.; Plaza, M.; Herrero, M.; Rodriguez-Meizoso, I.; Ibañez, E.; Reglero, G. Antiviral compounds obtained from microalgae commonly used as carotenoid sources. J. Appl. Phycol. 2012, 24, 731-741. [CrossRef]

114. Huheihel, M.; Ishanu, V.; Tal, J.; Arad, S.M. Activity of Porphyridium sp. polysaccharide against herpes simplex viruses in vitro and in vivo. J. Biochem. Biophys. Methods 2002, 50, 189-200. [CrossRef]

115. Talyshinsky, M.M.; Souprun, Y.Y.; Huleihel, M.M. Anti-viral activity of red microalgal polysaccharides against retroviruses. Cancer Cell Int. 2002, 2, 8. [CrossRef] [PubMed]

116. Radonić, A.; Thulke, S.; Achenbach, J.; Kurth, A.; Vreemann, A.; König, T.; Walter, C.; Possinger, K.; Nitsche, A. Anionic polysaccharides from phototrophic microorganisms exhibit antiviral activities to Vaccinia virus. J. Antivir. Antiretrovir. 2011, 2, 51-55.

117. Lee, J.B.; Hayashi, K.; Hirata, M.; Kuroda, E.; Suzuki, E.; Kubo, Y.; Hayashi, T. Antiviral sulfated polysaccharide from Navicula directa, a diatom collected from deep-sea water in Toyama Bay. Biol. Pharm. Bull. 2006, 29, 2135-2139. [CrossRef]

118. Graf, C.; Bernkop-Schnürch, A.; Egyed, A.; Koller, C.; Prieschl-Grassauer, E.; Morokutti-Kurz, M. Development of a nasal spray containing xylometazoline hydrochloride and iota-carrageenan for the symptomatic relief of nasal congestion caused by rhinitis and sinusitis. Int. J. Gen. Med. 2018, 11, 275-283. [CrossRef] [PubMed]

119. Alangaden, G.J. Nosocomial fungal infections: Epidemiology, infection control, and prevention. Infect. Dis. Clin. N. Am. 2011, 25, 201-225. [CrossRef]

120. Manuel, R.J.; Kibbler, C.C. The epidemiology and prevention of invasive Aspergillosis. J. Hospit. Infect. 1998, 39, 95-109. [CrossRef]

121. Wey, S.B.; Mori, M.; Pfaller, M.A.; Woolson, R.F.; Wenzel, R.P. Hospital-acquired candidemia: The attributable mortality and excess length of stay. Arch. Intern. Med. 1988, 148, 2642-2645. [CrossRef]

122. Washida, K.; Koyama, T.; Yamada, K.; Kita, M.; Uemura, D. Karatungiols A and B, two novel antimicrobial polyol compounds, from the symbiotic marine dinoflagellate Amphidinium sp. Tetrahedron Lett. 2006, 47, 2521-2525. [CrossRef]

123. Gueho, E.; Pesando, D.; Barelli, M. Proprietes antifongiques d'une diatomee Chaetoceros lauderi ralfs CC. Mycopathologia 1977, 60, 105-107.

124. Walter, C.S.; Mahesh, R. Antibacterial and antifungal activities of some marine diatoms in culture. Indian J. Mar. Sci. 2000, $29,238-242$.

125. Ghannoum, M.A.; Rice, L.B. Antifungal agents: Mode of action, mechanisms of resistance, and correlation of these mechanisms with bacterial resistance. Clin. Microbiol. Rev. 1999, 12, 501-517. [CrossRef]

126. Gastineau, R.; Hardivillier, Y.; Leignel, V.; Tekaya, N.; Morançais, M.; Fleurence, J.; Davidovich, N.; Jacquette, B.; Gaudin, P.; Hellio, C.; et al. Greening effect on oysters and biological activities of the blue pigments produced by the diatom Haslea karadagensis (Naviculaceae). Aquaculture 2012, 368, 61-67. 
127. Ghasemi, Y.; Moradian, A.; Mohagheghzadeh, A.; Shokravi, S.; Morowvat, M.H. Antifungal and antibacterial activity of the microalgae collected from paddy fields of Iran: Characterization of antimicrobial activity of Chroococcus dispersus. J. Biol. Sci. 2007, 7, 904-910. [CrossRef]

128. Anand, P.; Kunnumakkara, A.B.; Sundaram, C.; Harikumar, K.B.; Tharakan, S.T.; Lai, O.S.; Sung, B.; Aggarwal, B.B. Cancer is a preventable disease that requires major lifestyle changes. Pharm. Res. 2008, 25, 2097-2116. [CrossRef]

129. Chinery, R.; Brockman, J.A.; Peeler, M.O.; Shyr, Y.; Beauchamp, R.D.; Coffey, R.J. Antioxidants enhance the cytotoxicity of chemotherapeutic agents in colorectal cancer: A p53-independent induction of p21 WAF1/CIP1 via C/EBP $\beta$. Nat. Med. 1997, 3, 1233-1241. [CrossRef] [PubMed]

130. Burja, A.M.; Banaigs, B.; Abou-Mansour, E.; Burgess, J.G.; Wright, P.C. Marine cyanobacteria-A prolific source of natural products. Tetrahedron 2001, 57, 9347-9377. [CrossRef]

131. Singh, R.; Parihar, P.; Singh, M.; Bajguz, A.; Kumar, J.; Singh, S.; Singh, V.P.; Prasad, S.M. Uncovering potential applications of cyanobacteria and algal metabolites in biology, agriculture and medicine: Current status and future prospects. Front. Microbiol. 2017, 8, 515. [CrossRef]

132. Wang, H.; Liu, Y.; Gao, X.; Carter, C.L.; Liu, Z.R. The recombinant $\beta$ subunit of C-phycocyanin inhibits cell proliferation and induces apoptosis. Cancer Lett. 2007, 247, 150-158. [CrossRef]

133. Laroche, C.; Michaud, P. New developments and prospective applications for $\beta(1,3)$ glucans. Recent Pat. Biotechnol. 2007, 1 , 59-73. [CrossRef]

134. Sun, L.; Wang, L.; Zhou, Y. Immunomodulation and antitumor activities of different-molecular-weight polysaccharides from Porphyridium cruentum. Carbohydr. Polym. 2012, 87, 1206-1210. [CrossRef]

135. Geresh, S.; Mamontov, A.; Weinstein, J. Sulfation of extracellular polysaccharides of red microalgae: Preparation, characterization and properties. J. Biochem. Biophys. Methods 2002, 50, 179-187. [CrossRef]

136. Sheih, I.C.; Fang, T.J.; Wu, T.K.; Lin, P.H. Anticancer and antioxidant activities of the peptide fraction from algae protein waste. J. Agric. Food Chem. 2010, 58, 1202-1207. [CrossRef] [PubMed]

137. Talero, E.; García-Mauriño, S.; Ávila-Román, J.; Rodríguez-Luna, A.; Alcaide, A.; Motilva, V. Bioactive compounds isolated from microalgae in chronic inflammation and cancer. Mar. Drugs 2015, 13, 6152-6209. [CrossRef] [PubMed]

138. Abbas, A.B.; Lichtman, A.H. Ch.2 Innate Immunity. In Basic Immunology. Functions and Disorders of the Immune System, 3rd ed.; Saunders (Elsevier): Philadelphia, PA, USA, 2009; p. 312. ISBN 978-1-4160-4688-2.

139. Jellinger, K.A. Recent advances in our understanding of neurodegeneration. J. Neural. Transm. 2009, 116, 1111-1162.

140. Popa-Wagner, A.; Mitran, S.; Sivanesan, S.; Chang, E.; Buga, A.M. ROS and brain diseases: The good, the bad, and the ugly. Oxid. Med. Cell. Longev. 2013, 963520. [CrossRef]

141. Blagojević, D.; Babić, O.; Rašeta, M.; Šibul, F.; Janjušević, L.; Simeunović, J. Antioxidant activity and phenolic profile in filamentous cyanobacteria: The impact of nitrogen. J. Appl. Phycol. 2018, 30, 2337-2346. [CrossRef]

142. Khan, M.N.A.; Cho, J.Y.; Lee, M.C.; Kang, J.Y.; Park, N.G.; Fujii, H.; Hong, Y.K. Isolation of two anti-inflammatory and one pro-inflammatory polyunsaturated fatty acids from the brown seaweed Undaria pinnatifida. J. Agric. Food Chem. 2007, 55, 6984-6988. [CrossRef] [PubMed]

143. Steffens, D.; Lersch, M.; Rosa, A.; Scher, C.; Crestani, T.; Morais, M.G.; Costa, J.A.V.; Pranke, P. A new biomaterial of nanofibers with the microalga Spirulinaas scaffolds to cultivate with stem cells for use in tissue engineering. J. Biomed. Nanotechnol. 2013, 9 , 710-718. [CrossRef] [PubMed]

144. Díaz, M, M.T.; Pérez, C.; Sánchez, C.I.; Lauzurica, S.; Cañeque, V.; González, C.; De La Fuente, J. Feeding microalgae increases omega 3 fatty acids of fat deposits and muscles in light lambs. J. Food Compos. Anal. 2017, 56, 115-123. [CrossRef]

145. Nauroth, J.M.; Liu, Y.C.; Van Elswyk, M.; Bell, R.; Hall, E.B.; Chung, G.; Arterburn, L.M. Docosahexaenoic acid (DHA) and docosapentaenoic acid (DPAn-6) algal oils reduce inflammatory mediators in human peripheral mononuclear cells in vitro and paw edema in vivo. Lipids 2010, 45, 375-384. [CrossRef]

146. Ohgami, K.; Shiratori, K.; Kotake, S.; Nishida, T.; Mizuki, N.; Yazawa, K.; Ohno, S. Effects of astaxanthin on lipopolysaccharideinduced inflammation in vitro and in vivo. Investig. Ophthalmol. Vis. Sci. 2003, 44, 2694-2701. [CrossRef] [PubMed]

147. Arulselvan, P.; Fard, M.T.; Tan, W.S.; Gothai, S.; Fakurazi, S.; Norhaizan, M.E.; Kumar, S.S. Role of antioxidants and natural products in inflammation. Oxid. Med. Cell Longev. 2016, 5276130. [CrossRef]

148. Robertson, R.C.; Guihéneuf, F.; Bahar, B.; Schmid, M.; Stengel, D.B.; Fitzgerald, G.F.; Ross, R.P.; Stanton, C. The anti-inflammatory effect of algae-derived lipid extracts on lipopolysaccharide (LPS)-stimulated human THP-1 macrophages. Mar. Drugs 2015, 13, 5402-5424. [CrossRef] [PubMed]

149. Kang, S.M.; Kim, K.N.; Lee, S.H.; Ahn, G.; Cha, S.H.; Kim, A.D.; Yang, X.D.; Kang, M.C.; Jeon, Y.J. Anti-inflammatory activity of polysaccharide purified from AMG-assistant extract of Ecklonia cava in LPS-stimulated RAW 264.7 macrophages. Carbohydr. Polym. 2011, 85, 80-85. [CrossRef]

150. Zhao, P.; Zang, Z.; Xie, X.; Huang, A.; Wang, G. The influence of different flocculants on the physiological activity and fucoxanthin production of Phaeodactylum tricornutum. Process Biochem. 2014, 49, 681-687. [CrossRef]

151. Senni, K.; Pereira, J.; Gueniche, F.; Delbarre-Ladrat, C.; Sinquin, C.; Ratiskol, J.; Godeau, G.; Fischer, A.M.; Helley, D.; ColliecJouault, S. Marine polysaccharides: A source of bioactive molecules for cell therapy and tissue engineering. Mar. Drugs 2011, 9, 1664-1681. [CrossRef] 
152. Kim, J.H.; Lee, J.E.; Kim, K.H.; Kang, N.J. Beneficial effects of marine algae-derived carbohydrates for skin health. Mar. Drugs 2018, 16, 459. [CrossRef] [PubMed]

153. Bilal, M.; Rasheed, T.; Ahmed, I.; Iqbal, H.M.N. High value compounds from microalgae with industrial exploitability-A review. Front. Biosci. 2017, 9, 319-342.

154. Muñoz-Durango, N.; Fuentes, C.A.; Castillo, A.E.; González-Gómez, L.M.; Vecchiola, A.; Fardella, C.E.; Kalergis, A.M. Role of the renin-angiotensin-aldosterone system beyond blood pressure regulation: Molecular and cellular mechanisms involved in end-organ damage during arterial hypertension. Int. J. Mol. Sci. 2016, 17, 797.

155. Solomon, S.D.; Skali, H.; Bourgoun, M.; Fang, J.; Ghali, J.K.; Martelet, M.; Wojciechowski, D.; Ansmite, B.; Skards, J.; Laks, T.; et al. Effect of angiotensin-converting enzyme or vasopeptidase inhibition on ventricular size and function in patients with heart failure: The Omapatrilat Versus Enalapril Randomized Trial of Utility in Reducing Events (OVERTURE) echocardiographic study. Am. Heart J. 2005, 150, 257-262.

156. Ko, S.C.; Kang, N.; Kim, E.A.; Kang, M.C.; Lee, S.H.; Kang, S.M.; Lee, J.B.; Jeon, B.T.; Kim, S.K.; Park, S.J.; et al. A novel angiotensin I-converting enzyme (ACE) inhibitory peptide from a marine Chlorella ellipsoidea and its antihypertensive effect in spontaneously hypertensive rats. Process Biochem. 2012, 47, 2005-2011. [CrossRef]

157. Samarakoon, K.W.; Kwon, O.N.; Ko, J.Y.; Lee, J.H.; Kang, M.C.; Kim, D.; Lee, J.B.; Lee, J.S.; Jeon, Y.J. Purification and identification of novel angiotensin-I converting enzyme (ACE) inhibitory peptides from cultured marine microalgae (Nannochloropsis oculata) protein hydrolysate. J. Appl. Phycol. 2013, 25, 1595-1606.

158. Raposo, M.F.D.J.; Oliveira, S.E.; Castro, P.M.; Bandarra, N.M.; Morais, R.M. On the utilization of microalgae for brewery effluent treatment and possible applications of the produced biomass. J. Inst. Brew. 2010, 116, 285-292. [CrossRef]

159. Hayakawa, Y.; Hayashi, T.; Lee, J.B.; Ozawa, T.; Sakuragawa, N. Activation of heparin cofactor II by calcium Spirulan. J. Biol. Chem. 2000, 275, 11379-11382. [CrossRef]

160. Taylor, V.F.; Jackson, B.P. Concentrations and speciation of arsenic in New England seaweed species harvested for food and agriculture. Chemosphere 2016, 163, 6-13. [CrossRef]

161. Das, B.K.; Pradhan, J.; Pattnaik, P.; Samantaray, B.R.; Samal, S.K. Production of antibacterials from the freshwater alga Euglena viridis (Ehren). World J. Microbiol. Biotechnol. 2005, 21, 45-50. [CrossRef]

162. Bhagavathy, S.; Sumathi, P.; Bell, I.J.S. Green algae Chlorococcum humicola -a new source of bioactive compounds with antimicrobial activity. Asian Pac. J. Trop Biomed. 2011, 1, S1-S7. [CrossRef]

163. Hasui, M.; Matsuda, M.; Okutani, K.; Shigeta, S.; Hasui, M. In vitro antiviral activities of sulfated polysaccharides from a marine microalga (Cochlodinium polykrikoides) against human immunodeficiency virus and other enveloped viruses. Int. J. Biol. Macromol. 1995, 17, 293-297. [CrossRef]

164. Li, H.B.; Cheng, K.W.; Wong, C.C.; Fan, K.W.; Chen, F.; Jiang, Y. Evaluation of antioxidant capacity and total phenolic content of different fractions of selected microalgae. Food Chem. 2007, 102, 771-776. [CrossRef]

165. U.S. Food and Drug Administration (HHS). FDA Summary: Substances Generally Regarded as Safe (Final Rule). 2016. Available online: http:/ / www.fda.gov/AboutFDA/ReportsManualsForms/Reports/EconomicAnalyses/ucm517103.htm (accessed on 24 October 2016).

166. Wijffels, R.H. Potential of sponges and microalgae for marine biotechnology. Trends Biotechnol. 2008, 26, 26-31. [CrossRef] [PubMed]

167. Europen Food Safety Auhtority (EFSA). EU Novel Food Catalogue (v 1.1.). 2020. Available online: http://ec.europa.eu/food/ safety/novel_food/catalogue_en (accessed on 16 April 2020).

168. Kay, R.A.; Barton, L.L. Microalgae as food and supplement. Crit. Rev. Food. Sci. Nutr. 1991, 30, 555-573. [CrossRef] [PubMed]

169. Kumar, B.R.; Deviram, G.; Mathimani, T.; Duc, P.A.; Pugazhendhi, A. Microalgae as rich source of polyunsaturated fatty acids. Biocatal. Agric. Biotechnol. 2019, 17, 583-588. [CrossRef]

170. Hemaiswarya, S.; Raja, R.; Kumar, R.R.; Ganesan, V.; Anbazhagan, C. Microalgae: A sustainable feed source for aquaculture. World J. Microbiol. Biotechnol. 2011, 27, 1737-1746. [CrossRef]

171. Apandi, N.M.; Mohamed, R.M.S.R.; Al-Gheethi, A.; Kassim, A.H.M. Microalgal biomass production through phycoremediation of fresh market wastewater and potential applications as aquaculture feeds. Environ. Sci. Pollut. Res. 2019, 26, 3226-3242. [CrossRef]

172. Yucetepe, A.; Saroglu, O.; Bildik, F.; Ozcelik, B.; Daskaya-Dikmen, C. Optimisation of ultrasound-assisted extraction of protein from Spirulina platensis using RSM. Czech J. Food Sci. 2018, 36, 98-108. [CrossRef]

173. Madeira, M.S.; Cardoso, C.; Lopes, P.A.; Coelho, D.; Afonso, C.; Bandarra, N.M.; Prates, J.A. Microalgae as feed ingredients for livestock production and meat quality: A review. Livest. Sci. 2017, 205, 111-121. [CrossRef]

174. Sui, Y.; Vlaeminck, S.E. Dunaliella microalgae for nutritional protein: An undervalued asset. Trends Biotechnol. 2020, 38, 10-12. [CrossRef]

175. Yaakob, Z.; Ali, E.; Zainal, A.; Mohamad, M.; Takriff, M.S. An overview: Biomolecules from microalgae for animal feed and aquaculture. J. Biol. Res. 2014, 21, 6.

176. Nonwachai, T.; Purivirojkul, W.; Limsuwan, C.; Chuchird, N.; Velasco, M.; Dhar, A.K. Growth, nonspecific immune characteristics, and survival upon challenge with Vibrio harveyi in Pacific white shrimp (Litopenaeus vannamei) raised on diets containing algal meal. Fish Shellfish Immun. 2010, 29, 298-304. [CrossRef] [PubMed]

177. Dineshbabu, G.; Goswami, G.; Kumar, R.; Sinha, A.; Das, D. Microalgae-nutritious, sustainable aqua-and animal feed source. J. Funct Foods. 2019, 62, 103545.

178. Guedes, A, A.C.; Malcata, F.X. Nutritional value and uses of microalgae in aquaculture. Aquaculture 2012, 10, 59-78. 
179. Neupert, J.; Shao, N.; Lu, Y.; Bock, R. Genetic transformation of the model green alga Chlamydomonas reinhardtii. In Transgenic Plants; Dunwell, J., Wetten, A., Eds.; Springer: Cham, Switzerland, 2012.

180. Costa, D.F.A.; Quigley, S.P.; Isherwood, P.; McLennan, S.R.; Poppi, D.P. Supplementation of cattle fed tropical grasses with microalgae increases microbial protein production and average daily gain. J. Anim. Sci. 2016, 94, 2047-2058. [CrossRef]

181. Kulpys, J.; Paulauskas, E.; Pilipavicius, V.; Stankevicius, R. Influence of cyanobacteria Arthrospira (Spirulina) platensis biomass additive towards the body condition of lactation cows and biochemical milk indexes. Agron. Res. 2009, 7, 823-835.

182. Kholif, A.E.; Morsy, T.A.; Matloup, O.H.; Anele, U.Y.; Mohamed, A.G.; El-Sayed, A.B. Dietary Chlorella vulgaris microalgae improves feed utilization, milk production and concentrations of conjugated linoleic acids in the milk of Damascus goats. J. Agric. Sci. 2017, 155, 508-518. [CrossRef]

183. Shimkiene, A.; Bartkevichiute, Z.; Chernauskiene, J.; Shimkus, A.; Chernauskas, A.; Ostapchuk, A.; Nevitov, M.; Shimkiene, A. The influence of Spirulina platensis and concentrates on lambs' growth. Zhivotnov'dni Nauki 2010, 47, 9-14.

184. Ekmay, R.; Gatrell, S.; Lum, K.; Kim, J.; Lei, X.G. Nutritional and metabolic impacts of a defatted green marine microalgal (Desmodesmus sp.) biomass in diets for weanling pigs and broiler chickens. J. Agric. Food Chem. 2014, 62, $9783-9791$.

185. Wu, Y.B.; Li, L.; Wen, Z.G.; Yan, H.J.; Yang, P.L.; Tang, J.; Xie, M.; Hou, S.S. Dual functions of eicosapentaenoic acid-rich microalgae: Enrichment of yolk with n-3 polyunsaturated fatty acids and partial replacement for soybean meal in diet of laying hens. Poult. Sci. 2019, 98, 350-357. [CrossRef] [PubMed]

186. Bruneel, C.; Lemahieu, C.; Fraeye, I.; Ryckebosch, E.; Muylaert, K.; Buyse, J.; Foubert, I. Impact of microalgal feed supplementation on omega-3 fatty acid enrichment of hen eggs. J. Funct. Foods 2013, 5, 897-904. [CrossRef]

187. Gatrell, S.; Lum, K.; Kim, J.; Lei, X.G. Nonruminant Nutrition Symposium: Potential of defatted microalgae from the biofuel industry as an ingredient to replace corn and soybean meal in swine and poultry diets. J. Anim. Sci. 2014, 92, 1306-1314.

188. Qiu, S.; Wang, S.; Xiao, C.; Ge, S. Assessment of microalgae as a new feeding additive for fruit fly Drosophila melanogaster. Sci. Total Environ. 2019, 667, 455-463. [CrossRef]

189. Daneshvar, E.; Ok, Y.S.; Tavakoli, S.; Sarkar, B.; Shaheen, S.M.; Hong, H.; Luo, Y.; Rinklebe, J.; Song, H.; Bhatnagar, A. Insights into upstream processing of microalgae: A review. Bioresour. Technol. 2021, 329, 124870. [CrossRef] [PubMed]

190. Narala, R.R.; Garg, S.; Sharma, K.K.; Thomas-Hall, S.R.; Deme, M.; Li, Y.; Schenk, P.M. Comparison of microalgae cultivation in photobioreactor, open raceway pond, and a two-stage hybrid system. Front. Energy Res. 2016, 4, 29. [CrossRef]

191. Coêlho, D.D.F.; Tundisi, L.L.; Cerqueira, K.S.; Rodrigues, J.R.D.S.; Mazzola, P.G.; Tambourgi, E.B.; Souza, R.R.D. Microalgae: Cultivation aspects and bioactive compounds. Braz. Arch. Biol. Technol. 2019, 62, e19180343.

192. Ranadheer, P.; Kona, R.; Sreeharsha, R.V.; Venkata Mohan, S. Non-lethal nitrate supplementation enhances photosystem II efficiency in mixotrophic microalgae towards the synthesis of proteins and lipids. Bioresour. Technol. 2019, 283, 373-377. [CrossRef]

193. Chiranjeevi, P.; Venkata Mohan, S. Diverse acidogenic effluents as feedstock for microalgae cultivation: Dual phase metabolic transition on biomass growth and lipid synthesis. Bioresour. Technol. 2017, 242, 191-196. [CrossRef]

194. Suparmaniam, U.; Lam, M.K.; Uemura, Y.; Lim, J.W.; Lee, K.T.; Shuit, S.H. Insights into the microalgae cultivation technology and harvesting process for biofuel production: A review. Renew. Sust. Energ. Rev. 2019, 115, 109361. [CrossRef]

195. Chaisutyakorn, P.; Praiboon, J.; Kaewsuralikhit, C. The effect of temperature on growth and lipid and fatty acid composition on marine microalgae used for biodiesel production. J. Appl. Phycol. 2018, 30, 37-45. [CrossRef]

196. Khalil, Z.I.; Asker, M.M.; El-Sayed, S.; Kobbia, I.A. Effect of $\mathrm{pH}$ on growth and biochemical responses of Dunaliella bardawil and Chlorella ellipsoidea. World J. Microbiol. Biotechnol. 2010, 26, 1225-1231. [CrossRef]

197. Venkata Mohan, S.; Devi, M.P. Salinity stress induced lipid synthesis to harness biodiesel during dual mode cultivation of mixotrophic microalgae. Bioresour. Technol. 2014, 165, 288-294. [CrossRef] [PubMed]

198. De Oliveira, C.Y.B.; Viegas, T.L.; da Silva, M.F.O.; Fracalossi, D.M.; Lopes, R.G.; Derner, R.B. Effect of trace metals on growth performance and accumulation of lipids, proteins, and carbohydrates on the green microalga Scenedesmus obliquus. Aquac. Int. 2020; 1-10. [CrossRef]

199. Rastogi, R.P.; Madamwar, D.; Nakamoto, H.; Incharoensakdi, A. Resilience and self-regulation processes of microalgae under UV radiation stress. J. Photochem. Photobiol. C Photochem. Rev. 2019, 100322. [CrossRef]

200. Singh, G.; Patidar, S.K. Microalgae harvesting techniques: A review. J. Environ. Manag. 2018, 217, 499-508. [CrossRef]

201. Saha, S.K.; Murray, P. Exploitation of microalgae species for nutraceutical purposes: Cultivation aspects. Fermentation 2018, 4 , 46. [CrossRef]

202. Shah, M.; Mahfuzur, R.; Liang, Y.; Cheng, J.J.; Daroch, M. Astaxanthin-producing green microalga Haematococcus pluvialis: From single cell to high value commercial products. Front. Plant Sci. 2016, 7, 531. [CrossRef] [PubMed]

203. Hemalatha, M.; Sravan, J.S.; Min, B.; Venkata Mohan, S. Microalgae-biorefinery with cascading resource recovery design associated to dairy wastewater treatment. Bioresour. Technol. 2019, 284, 424-429. [CrossRef]

204. Venkata Mohan, S.; Devi, M.P.; Mohanakrishna, G.; Amarnath, N.; Babu, M.L.; Sarma, P.N. Potential of mixed microalgae to harness biodiesel from ecological water-bodies with simultaneous treatment. Bioresour. Technol. 2011, 102, 1109-1117. [CrossRef]

205. Aziz, M.M.A.; Kassim, K.A.; Shokravi, Z.; Jakarni, F.M.; Liu, H.Y.; Zaini, N.; Tan, L.S.; Islam, A.S.; Shokravi, H. Two-stage cultivation strategy for simultaneous increases in growth rate and lipid content of microalgae: A review. Renew. Sust. Energ. Rev. 2020, 119, 109621. [CrossRef] 
206. Devi, M.P.; Subhash, G.V.; Venkata Mohan, S. Heterotrophic cultivation of mixed microalgae for lipid accumulation and wastewater treatment during sequential growth and starvation phases: Effect of nutrient supplementation. Renew Energy 2012, 43, 276-283. [CrossRef]

207. Gangl, D.; Zedler, J.A.; Rajakumar, P.D.; Martinez, E.M.; Riseley, A.; Włodarczyk, A.; Purton, S.; Sakuragi, Y.; Howe, C.J.; Jensen, P.E.; et al. Biotechnological exploitation of microalgae. J. Exp. Bot. 2015, 66, 6975-6990.

208. Caetano, N.S.; Martins, A.A.; Gorgich, M.; Gutiérrez, D.M.; Ribeiro, T.J.; Ribeiro, T.J.; Mata, T.M. Flocculation of Arthrospira maxima for improved harvesting. Energy Rep. 2020, 6, 423-428. [CrossRef]

209. Monte, J.; Sá, M.; Galinha, C.F.; Costa, L.; Hoekstra, H.; Brazinha, C.; Crespo, J.G. Harvesting of Dunaliella salina by membrane filtration at pilot scale. Sep. Purif. Technol. 2018, 190, 252-260. [CrossRef]

210. Sharma, K.K.; Garg, S.; Li, Y.; Malekizadeh, A.; Schenk, P.M. Critical analysis of current microalgae dewatering techniques. Biofuels 2013, 4, 397-407. [CrossRef]

211. Okoro, V.; Azimov, U.; Munoz, J.; Hernandez, H.H.; Phan, A.N. Microalgae cultivation and harvesting: Growth performance and use of flocculants-A review. Renew. Sustain. Energy Rev. 2019, 115, 109364. [CrossRef]

212. Mathimani, T.; Mallick, N. A comprehensive review on harvesting of microalgae for biodiesel-key challenges and future directions. Renew. Sustain. Energy Rev. 2018, 91, 1103-1120. [CrossRef]

213. Safi, C.; Frances, C.; Ursu, A.V.; Laroche, C.; Pouzet, C.; Vaca-Garcia, C.; Pontalier, P.Y. Understanding the effect of cell disruption methods on the diffusion of Chlorella vulgaris proteins and pigments in the aqueous phase. Algal Res. 2015, 8, 61-68. [CrossRef]

214. Phong, W.N.; Show, P.L.; Ling, T.C.; Juan, J.C.; Ng, E.P.; Chang, J.S.; Pouzet, C.; Vaca-Garcia, C. Mild cell disruption methods for bio-functional proteins recovery from microalgae-Recent developments and future perspectives. Algal Res. 2018, 31, 506-516. [CrossRef]

215. Günerken, E.; D’Hondt, E.; Eppink, M.H.M.; Garcia-Gonzalez, L.; Elst, K.; Wijffels, R.H. Cell disruption for microalgae biorefineries. Biotechnol. Adv. 2015, 33, 243-260.

216. Lorente, E.; Hapońska, M.; Clavero, E.; Torras, C.; Salvadó, J. Microalgae fractionation using steam explosion, dynamic and tangential cross-flow membrane filtration. Bioresour. Technol. 2017, 237, 3-10. [CrossRef] [PubMed]

217. Postma, P.R.; Miron, T.L.; Olivieri, G.; Barbosa, M.J.; Wijffels, R.H.; Eppink, M.H.M. Mild disintegration of the green microalgae Chlorella vulgaris using bead milling. Bioresour. Technol. 2015, 184, 297-304.

218. Cuellar-Bermudez, S.P.; Aguilar-Hernandez, I.; Cardenas-Chavez, D.L.; Ornelas-Soto, N.; Romero-Ogawa, M.A.; Parra-Saldivar, R. Extraction and purification of high-value metabolites from microalgae: Essential lipids, astaxanthin and phycobiliproteins. Microb. Biotechnol. 2015, 8, 190-209. [CrossRef]

219. Tiwari, B.K. Ultrasound: A clean, green extraction technology. Trends Anal. Chem. 2015, 71, 100-109. [CrossRef]

220. Mittal, R.; Tavanandi, H.A.; Mantri, V.A.; Raghavarao, K.S.M.S. Ultrasound assisted methods for enhanced extraction of Phycobiliproteins from marine macro-algae, Gelidium pusillum (Rhodophyta). Ultrason. Sonochem. 2017, 38, 92-103. [CrossRef] [PubMed]

221. Sutanto, H.; Suzery, M. Phyocyanin extraction from microalgae Spirulina platensis assisted by ultrasound irradiation: Effect of time and temperature. Songklanakarin J. Sci. Technol. 2016, 38, 391-398.

222. Tan, J.S.; Lee, S.Y.; Chew, K.W.; Lam, M.K.; Lim, J.W.; Ho, S.H.; Show, P.L. A review on microalgae cultivation and harvesting, and their biomass extraction processing using ionic liquids. Bioengineered 2020, 11, 116-129. [CrossRef] [PubMed]

223. Kapoore, R.V.; Butler, T.O.; Pandhal, J.; Vaidyanathan, S. Microwave-assisted extraction for microalgae: From biofuels to biorefinery. Biology 2018, 7, 18. [CrossRef]

224. Cooney, M.; Young, G.; Nagle, N. Extraction of bio-oils from microalgae. Sep. Purif. Rev. 2016, 38, 291-325. [CrossRef]

225. Rodriguez-Jasso, R.M.; Mussatto, S.I.; Pastrana, L.; Aguilar, C.N.; Teixeira, J.A. Microwave-assisted extraction of sulfated polysaccharides (fucoidan) from brown seaweed. Carbohydr. Polym. 2011, 86, 1137-1144. [CrossRef]

226. Kim, D.Y.; Vijayan, D.; Praveenkumar, R.; Han, J.I.; Lee, K.; Park, J.Y.; Chang, W.S.; Lee, J.S.; Oh, Y.K. Cell-wall disruption and lipid/astaxanthin extraction from microalgae: Chlorella and Haematococcus. Bioresour. Technol. 2016, 199, 300-310. [CrossRef] [PubMed]

227. Molino, D.A.; Mehariya, S.; Di Sanzo, G.; Larocca, V.; Martino, M.; Leone, G.P.; Marino, T.; Chianese, S.; Balducchi, R.; Musmarra, D. Recent developments in supercritical fluid extraction of bioactive compounds from microalgae: Role of key parameters, technological achievements and challenges. J. $\mathrm{CO}_{2}$ Util. 2020, 36, 196-209.

228. Singh, D.; Gupta, A.; Wilkens, S.L.; Mathur, A.S.; Tuli, D.K.; Barrow, C.J.; Puri, M. Understanding response surface optimisation to the modeling of Astaxanthin extraction from a novel strain Thraustochytrium sp. S7. Algal Res. Algal Res. 2015, 11, 113-120.

229. Negi, S.; Pandey, A.K. Ionic liquid pretreatment. Pretreat. Biomass Process. Technol. 2014, 137-155. [CrossRef]

230. Lee, S.Y.; Vicente, F.A.; De Silva, F.A.; Sintra, T.E.; Taha, M.; Khoiroh, I.; Coutinho, J.A.; Show, P.L.; Ventura, S.P. Evaluating self-buffering ionic liquids for biotechnological applications. ACS Sustain. Chem Eng. 2015, 3, 3420-3428. [CrossRef]

231. Zinnai, A.; Sanmartin, C.; Taglieri, I.; Andrich, G.; Venturi, F. Supercritical fluid extraction from microalgae with high content of LC-PUFAs. A case of study: Sc-CO $\mathrm{CO}_{2}$ oil extraction from Schizochytrium sp. J. Supercrit. Fluids 2016, 116, $126-131$.

232. Leone, G.P.; Balducchi, R.; Mehariya, S.; Martino, M.; Larocca, V.; Di Sanzo, G.; Iovine, A.; Casella, P.; Marino, T.; Karatza, D.; et al. Selective Extraction of $\omega-3$ fatty acids from Nannochloropsis sp. using supercritical $\mathrm{CO}_{2}$ extraction. Molecules 2019, $24,2406$. [CrossRef] [PubMed] 
233. Molino, A.; Martino, M.; Larocca, V.; Di Sanzo, G.; Spagnoletta, A.; Marino, T.; Karatza, D.; Iovine, A.; Mehariya, S.; Musmarra, D. Eicosapentaenoic acid extraction from Nannochloropsis gaditana using carbon dioxide at supercritical conditions. Mar. Drugs 2019, 17, 132.

234. Herrero, M.; Sanchez-Camargo, A.P.; Cifuentes, A.; Ibanez, E. Plants, seaweeds, micro-algae and food by-products as natural sources of functional ingredients obtained using pressurized liquid extraction and supercritical fluid extraction. Trends Anal. Chem. 2015, 71, 26-38. [CrossRef]

235. Gallego, R.; Montero, L.; Cifuentes, A.; Ibáñez, E.; Herrero, M. Green extraction of bioactive compounds from microalgae. J. Anal. Test. 2018, 2, 109-123. [CrossRef]

236. Gilbert-López, B.; Barranco, A.; Herrero, M.; Cifuentes, A.; Ibáñez, E. Development of new green processes for the recovery of bioactives from Phaeodactylum tricornutum. Food Res. Int. 2017, 99, 1056-1065. [CrossRef]

237. Gerken, H.G.; Donohoe, B.; Knoshaug, E.P. Enzymatic cell wall degradation of Chlorellavulgaris and other microalgae for biofuels production. Planta 2013, 237, 239-253. [CrossRef] [PubMed]

238. Tang, S.; Hettiarachchy, N.S.; Shellhammer, T.H. Protein extraction from heat-stabilized defatted rice bran. 1. Physical processing and enzyme treatments. J. Agric. Food Chem. 2002, 50, 7444-7448. [CrossRef]

239. Kang, K.H.; Qian, Z.J.; Ryu, B.; Karadeniz, F.; Kim, D.; Kim, S.K. Antioxidant peptides from protein hydrolysate of microalgae Navicula incerta and their protective effects in HepG2/CYP2E1 cells induced by ethanol. Phyther. Res. 2012, 26, 1555-1563. [CrossRef]

240. Taher, H.; Al-Zuhair, S.; Al-Marzouqi, A.H.; Haik, Y.; Farid, M. Effective extraction of microalgae lipids from wet biomass for biodiesel production. Biomass Bioenergy 2014, 66, 159-167. [CrossRef] 